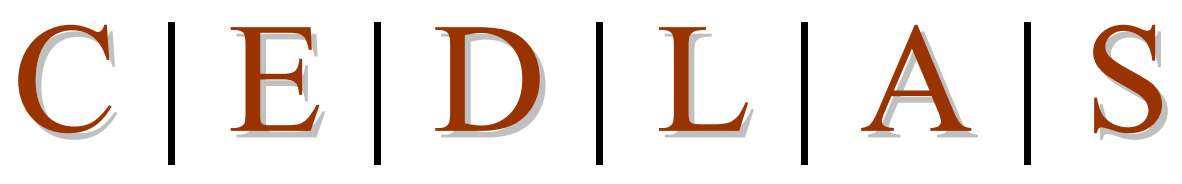

Centro de Estudios

Distributivos, Laborales y Sociales

Maestría en Economía

Facultad de Ciencias Económicas

Universidad Nacional de la Plata

\title{
School Management in Developing Countries
}

\section{Sebastian Galiani y Ricardo Perez-Truglia}

Documento de Trabajo Nro. 147

Julio, 2013

ISSN 1853-0168 


\title{
EDUCATION POLICY IN DEVELOPING COUNTRIES
}

\author{
Paul Glewwe, editor
}

\section{Chapter 6}

\section{School Management in Developing Countries}

$$
\text { by }
$$

Sebastian Galiani (Washington University in St. Louis)

Ricardo Perez-Truglia (Harvard University and Universidad de San Andres)

We thank useful comments from Jere Behrman, Paul Glewwe, Eric Hanushek, Laura Jaitman, Karthik Muralidharan, Lant Pritchett, discussants in the Conference "Education Policy in Developing Countries: What Do We Know, and What Should We Do to Understand What We Don’t Know?" as well as comments from other participants. Manuel Puente provided excellent research assistance. We acknowledge funding from the Weidenbaum Center at Washington University in St. Louis. 


\section{Introduction}

The developing world has implemented many different policies to catch up with the educational outcomes observed in the more advanced countries. In the past, policies were usually based on the premise that increasing the spending on education inputs would improve educational attainment. However, the link between spending on school inputs and student performance does not seem strong enough to account for the gap between the developing world and OECD countries. Therefore, in recent years considerable attention has been given to school management. Thus, this chapter explores the literature on interventions that focus on the way in which resources are managed, instead of focusing on the amount of resources used.

We define School Management as the system through which schools are organized to manage their resources. It includes three main branches: the school market (whether schools are public or private, and the regulation of competition in the schooling system), the administration of schools (whether the system is centralized or there is a school-based management of power, knowledge and budget) and the school organization (involving the curriculum, class-size, tracking of students, incentives and contracts to teachers, among others).

In this chapter we review the empirical literature on three different aspects of School Management. Firstly, we address the effect of school decentralization on educational outcomes (Section III). Secondly, we analyze topics related to the tracking of students within schools (Section IV) and thirdly, we explore the effect of different teacher incentive schemes, including pay for performance and contract teachers (Section V). The topics studied are timely given the recently adopted reforms in these areas. Recent experience with these reforms provides a body of evidence which can be used to reach some conclusions regarding 
their effectiveness. By no means is our list exhaustive. In fact, in this volume there are interesting analyses of other relevant issues that fall under our broad definition of School Management, such as school competition (Chapter 7) and topics related to incentives for parents and students (sections 3 and 4 in Chapter 5). Lastly, we do not cover other important issues, such as curriculum design, for which the evidence is still limited.

The aim of this Chapter is to introduce the big questions regarding school decentralization, tracking of students and teacher incentives, as well as to explore the main trade-offs implied in the policies targeted at those aspects of School Management. There is controversy about the efficacy of these policies and the way they should be applied under different contexts. For example, economists and some policy-makers seem to be sympathetic to decentralization measures, but there is no consensus about the potential benefits of tracking and contract teachers. Furthermore, while reforms involving school decentralization and teacher incentives have been relatively widespread during the last decade in the developing world, tracking has lacked similar popularity.

Regarding the methodological approach adopted in this chapter, we focus especially on the empirical evidence in each topic. Firstly, we provide a simple theoretical framework to illustrate the main potential gains and sources of trade-offs. With the framework in mind, we construct a large - though non-exhaustive - review of empirical papers that study the topic at hand. The ultimate goal of the chapter is to understand the causal effect of these types of interventions on educational performance. Therefore, identification issues are of first order importance. In the review we mainly include papers that exploit experimental or quasiexperimental identification strategies. Those methods have proven to be the most accurate in reconstructing the counterfactual needed to study the fundamental problem of causal inference. Nevertheless, we also include important cross-sectional studies of correlations 
between variables of interest, but we always make clear the potential sources and direction of possible bias in the non-experimental estimates.

Another methodological concern that is important for understanding the message we want to transmit concerns the comparison across results that comes from different types of studies. For example, in the tracking section we report observational or quasi-experimental studies that find no (or even a negative) effect of this intervention on students' performance, while we also review randomized experiments showing a positive impact of tracking. The way in which we should reconcile the results is to understand the heterogeneity of both the settings and the methods exploited. Unfortunately, for the time being, different settings are studied with different methodologies, so it is not obvious whether the differences in findings across studies are due only to differences in methodology or also to differences in the true parameters across the different settings. Nevertheless, a priori, we rely more on the results reported in experimental studies due to their higher credibility in identifying the causal effects of the interventions.

The last methodological issue we want to emphasize is closely related to the previous one. Even though experimental studies are internally valid, they do not necessarily have external validity (an issue obviously not exclusive to experimental studies, though). Therefore, the results cannot be generalized without further assumptions. Furthermore, external validity issues are somewhat more pressing when the effects of the interventions are heterogeneous across populations. For example, we show that in the case of tracking the effects of this intervention are highly dependent on the distribution of students' performance. Essentially, it is important to know whether the distribution is bimodal or uni-modal. Assumptions regarding this distribution will be needed to extend the experimental results from one setting to other settings: e.g., the distribution of students is probably very different 
in the US and Kenya. ${ }^{1}$ This fact, of course, does not diminish at all the importance of a study conducted under particular conditions. What it is more, we are often specifically interested in understanding how a policy or intervention works in a specific context.

Our main findings regarding the three School Management interventions studied in this chapter are the following. Decentralization programs seem to be successful in increasing the average performance of students. However, the better-off communities or schools tend to profit more from this intervention; thus future studies should attempt to understand how school autonomy affects poor and wealthy communities differently. Regarding tracking, the experimental evidence is still scarce, but it seems, at least in the context of a poor country where student performance is highly heterogeneous, that tracking increases the performance of all students. Finally, the results of teacher incentives interventions are generally positive, though the precise design of the compensation scheme is key for producing long-lasting improvements in learning. Also, in very poor countries, contract teachers have positive results in reducing absenteeism of teachers and improving the performance of students. However, understanding whether these results can be attributed to incentives, decentralization of hiring decisions or other mechanisms is essential to improving contract design for tenured civil service teachers and to better benefit from the combination of the two types of teachers.

Finally, we would like to point out that in most of the studies reviewed - as in the majority of impact evaluation papers - the focus is on the average treatment effect on the

\footnotetext{
${ }^{1}$ There is also the concern that the results are not robust when the experiment is scaled-up. When the policies are applied outside the controlled experiment, the behaviors of the agents may change, altering the effects previously identified. For instance, in the tracking experiments - as we review later - the allocation of teachers to sections is random, while in a non-experimental setup there might be sorting of teachers (see Pop-Eleches and Urquiola, 2011).
} 
treated population, which can be interpreted as the effect of the interventions on a random treated unit. The final assessment of these effects, however, would depend on the "welfare function" implicitly used by society to judge the results of the different policies and programs adopted. Nevertheless, as mentioned above, some programs may generate a gain on average but at the same time an increase in inequality. In those cases, the fact that there is a positive effect on average is genuinely valuable, yet it might be worth looking for complementary policy instruments to compensate for the increase in inequality, especially in cases when the cost of redistribution is high. The type and cost of the complementary interventions would depend on the context. We discuss these interventions in Section VI.

Section VII concludes and suggests some challenges for future research. The Appendix summarizes the main findings and methodologies of the reviewed papers.

\section{Improving Educational Outcomes: School Inputs and School Management}

Improving educational outcomes is one of the top priorities in most countries, especially in the developing world, which lags behind high income countries in many indicators. This concern is partially driven by the idea that the formation of human capital through education is one of the main drivers of economic growth.

For many years, the goal of education policies in developing countries was to increase spending on school inputs, such as the quantity and quality of teachers, school infrastructure, etc. However, the available evidence suggests that the correlation between per-student spending and student performance is not very robust. And more importantly, even if one considers the studies with credible identification strategies that find positive impacts of 
school inputs on educational attainment, the effects seem to be relatively modest and thus insufficient to help the developing world catch up with developed countries.

For example, thorough cross-country studies, such as Fuchs and Woessmann (2007) or Hanushek and Kimko (2000), find a weak relationship between per-student spending and test scores; a similar pattern has been found by Hanushek and Luque (2003), who evaluate the effect of class size, teacher experience and education on test scores. ${ }^{2}$ Furthermore, they find no evidence supporting the conventional view that school resources are relatively more important in poor countries. ${ }^{3}$ In contrast, Barro and Lee (2001), using panel data with fixed effects, find positive and significant results of increasing school resources. ${ }^{4}$

The micro-evidence is in line with the macro evidence. There have been several papers employing experiments or quasi-experiments to study the effect of input-based policy interventions on educational outcomes, and they also find modest results. One typical example of these interventions is reducing class size. For example, Angrist and Lavy (1999) employ a regression discontinuity design to exploit a rule that determines the division into classes in public schools in Israel (the Maimonides rule). These authors find that reducing class size induces a significant increase in reading and math scores for 5 th graders and a

\footnotetext{
${ }^{2}$ They used a cross-section of 37 countries in the TIMSS (Third International Mathematics and Science Study) data.

${ }^{3}$ See also Hanushek and Woessmann (2011) for an extensive survey.

${ }^{4}$ Only a weak relationship between spending and student outcomes has also been found in the time series variation within a given country. For example, Hanushek (2006) shows that even though the real spending per pupil in the US rose considerably through the period 1960-2000, the performances of students showed little improvement. Gundlach and Woessmann (2001) study 6 Asian countries between 1980 and 1994, reaching a similar conclusion: when inputs significantly increased in that period, cognitive achievement of pupils did not change substantially.
} 
smaller increase in reading scores for 4th graders, while no effect is found for 3rd graders. Kruger (1999) studies Tennessee's STAR Project, which randomized kindergarten students to small or regular-sized classes, and followed them for four years. The effects of a small class on student performance on standardized tests are positive on average, but modest. Chapter 2 in this volume provides a detailed review of school resources programs in developing countries and concludes that such programs have modest effects on student outcomes.

In summary, there does not seem to be a strong relationship between school inputs and educational outcomes. Given the large differences across countries in educational attainment, ${ }^{5}$ we might wonder which other interventions might help reduce these disparities. More specifically, we are interested in factors that could be affected by public policies. In fact, since the late 1990s the literature has been shifting towards the study of School Management reforms. The first contributions compared performance across countries with different school systems, but recently some studies exploited quasi-experimental and experimental identification strategies. The topics analyzed include school autonomy, external/exit exams and other accountability measures. ${ }^{6}$ Other institutional features that have been analyzed include the level of competition from private schools ${ }^{7}$ and characteristics of the pre-primary education. ${ }^{8}$

\footnotetext{
${ }^{5}$ According to PISA (2009), the difference between OECD and non-OECD members is 1-2 standard deviations in test scores.

${ }^{6}$ See for example Bishop (1995, 1999 and 2006), Woessmann (2005) and Woessmann et. al. (2009); and for a full review see Hanushek and Woessmann, (2011).

${ }^{7}$ For example Woessmann et al (2009), Vandenberghe and Robin (2004) and Corten and Dronkers (2006).

${ }^{8}$ For example, see Schouetz et al (2008), Berlinski et al (2009), and Chapter 3 in this volume.
} 
We consider that School Management might be one direction in which we could find an answer for how to improve educational outcomes, in light of the weak contribution of school resources. Finally, we would like to emphasize that an important advantage of some School Management interventions is that if they improve educational outcomes, they would likely be cost-effective as, in general, no extra resources are needed; only the existing ones should be managed in a different way. This is especially encouraging for developing countries, which typically face very tight budget constraints.

\section{School Decentralization}

Decentralization is the delegation of the management of resources to lower levels of the public administration, which leads to local provision of decentralized services.

Decentralization of public services is a major institutional innovation throughout the world (Bird and Vaillancourt, 1998) and there is an ongoing wave of decentralization in the developing world. ${ }^{9}$ In particular, school decentralization has been advocated by public officers and international organizations worldwide. ${ }^{10}$

\footnotetext{
9 Ten percent of the World Bank's education portfolio for the period 2000-2006 supported decentralization programs (approximately 15 out of 157 projects); see Barrera-Osorio et al (2009).

${ }^{10}$ For example, the Program for International Student Assessment (PISA) in the 2009 Assessment Framework appraised school autonomy: "Many of the world's best-performing education systems have moved from bureaucratic 'command and control' environments towards school systems in which the people at the frontline have much more control of the way resources are used, people are deployed, the work is organized and the way in which the work gets done. They provide considerable discretion to school heads and school faculties in determining how resources are allocated, a factor which the report shows to be closely related to school performance when combined with effective accountability systems." (PISA 2009, p. 4)
}

Glewwe, Chapter 6, p.9 
The main argument in support of decentralization in general, and school decentralization in particular, is that it brings decisions closer to the people, thereby alleviating information asymmetries, improving accountability and targeting the needs of the communities. However, decentralization can also degrade service provision in poor communities that lack the ability to voice and defend their preferences, or where local authorities have weak technical capabilities to manage resources (Galiani et al, 2008).

A. Theoretical Framework. In order to discuss the trade-offs implied in decentralization, we provide a simple theoretical framework based on Galiani et al (2008). For the sake of simplicity, in the model we introduce decentralization as a binary choice. Assume there are $i=1,2, \ldots, I$ provinces, and within each one of them there are different communities $\mathrm{j}=1,2, \ldots, \mathrm{J}$. Each community $i j$ has a representative school. In order to produce education, $e_{i j}$, the government makes an effort $b_{i j}$ in each community. This effort is determined by the spending on two educational inputs, $b_{i j}^{a} \geq 0$ and $b_{i j}^{b} \geq 0$ (for instance, the government can invest in teachers and non-teacher educational inputs):

$$
b_{i j}=\gamma_{i j} b_{i j}^{a}+\left(1-\gamma_{i j}\right) b_{i j}^{b}
$$

This linear functional form has extreme implications: if $\gamma_{i j}$ were observable and $\gamma_{i j}>\frac{1}{2}$ $\left(\gamma_{i j}<\frac{1}{2}\right)$ then the government would only invest in $b_{i j}^{a}\left(b_{i j}^{b}\right)$, while if $\gamma_{i j}=\frac{1}{2}$ the government would be indifferent between any combination of $b_{i j}^{a}$ and $b_{i j}^{b}$. We choose this extreme functional form to keep the algebra simple.

In a decentralized government the decision-makers are more aware of the needs of the local communities: the decentralized governments can observe their own $\gamma_{i j}$ directly. On the 
other hand, we assume that the central government only knows the statistical distribution of $\gamma_{i j}$ across communities, but it does not know the $\gamma_{i j}$ of any particular community. Each community also invests its own managerial effort, $a_{i j}$, in the production of education (for example through voicing local preferences and demands). The production technology for education is given by:

$$
e_{i j}=\left(\left(\kappa_{i j} a_{i j}\right)^{\alpha}+\left(b_{i j}\right)^{\alpha}\right)^{\frac{1}{\alpha}}
$$

The parameter $0<\alpha<1$ captures the degree of complementarity between the efforts of the community and the government. The parameter $0 \leq \kappa_{i j}<1$ represents the efficiency of community $i j$ 's effort. Since the authorities are closer to the people, a decentralized government can better complement and exploit the efforts of its members. We will represent this fact by assuming that $\kappa_{i j}=0 \forall i \forall j$ when education is provided centrally and $\kappa_{i j}$ can be positive if the system is decentralized.

In the centralized case, the problem of the government is very simple: since this case implies $\kappa_{i j}=0 \forall i \forall j$, every community will always choose $a_{i j}^{c}=0$ (no managerial effort at the community level). The only source of (unobserved) heterogeneity across communities is given by the parameter $\gamma_{i j}$. For the sake of simplicity, we assume that the distribution of $\gamma_{i j}$ has mean $\frac{1}{2}$ and is symmetric around $\frac{1}{2}$. Under regularity conditions, that would imply that the government will split a given investment $b_{i j}$ in equal parts among $b_{i j}^{a}$ and $b_{i j}^{b}$. Finally, assume that the central government's opportunity cost from spending $b_{i j}$ on education is $\left(\sum_{i j} b_{i j}^{\frac{2}{\phi}}\right)^{\phi}$. The quadratic functional form ensures that the opportunity cost is convex. The 
parameter $0<\phi \leq 1$ represents the economies of scale from providing the public good centrally, where a lower $\phi$ suggests stronger economies of scale. Under a decentralized government the cost is given by $\sum_{i j} b_{i j}^{2}$. Finally, denote $N=I^{*} J$ to the total number of representative schools.

The problem of the centralized government becomes: $\operatorname{Max}_{\left\{b_{i j}\right\}} N \cdot b_{i j}-\left(N \cdot b_{i j}^{\frac{2}{\phi}}\right)^{\phi}$

And the solution is: $b_{i j}^{c}=e_{i j}^{c}=\frac{N^{1-\phi}}{2} \forall i \forall j$.

Now we can turn to the case of decentralization. The benevolent government maximizes the utility of each community, but using weights $\theta_{i j}>0$ - where a higher value of $\theta_{i j}$ indicates that the government has a stronger preference for educational outcomes in community $i j$. This captures the fact that local preferences between spending on education and other spending can be different in local communities than for the central government. We assume that under centralization $\theta_{i j}=1 \forall(i, j)$. Under decentralization it could be the case that the local governments may be influenced by local elites who might bias the provision of public services against the poor, so $\theta_{i j}<1$ in poorer communities (Bardhan and Mookherjee, 2005).

The timing of the model is as follows. The government first decides its managerial effort $b_{i j}$ in each community. Communities then observe the government contribution and choose their own managerial effort $a_{i j}$. Remember that the local government observes $\gamma_{i j}$. To 
keep the algebra short, we denote: $\hat{\gamma}_{i j}=\max \left\{\gamma_{i j}, 1-\gamma_{i j}\right\}$. Therefore, $\hat{\gamma}_{i j}-\frac{1}{2}$ is a measure of how "special" the needs of community $i j$ are, relative to the average needs.

The equilibrium under decentralization is derived in Appendix $\mathrm{A}-$ the derivation is similar to that of the centralized case. The educational outcome under decentralization is:

$$
e_{i j}^{d}=\frac{\theta_{i j} \hat{\gamma}_{i j}^{2}}{2}\left(1-\kappa_{i j}^{\frac{\alpha}{1-\alpha}}\right)^{\frac{\alpha-2}{\alpha}}=\frac{\theta_{i j} \hat{\gamma}_{i j}^{2}}{2} \lambda\left(\kappa_{i j}, \alpha\right)
$$

where it can be shown that $\partial \lambda\left(\kappa_{i j}, \alpha\right) / \partial \kappa_{i j}>0$ and $\partial \lambda\left(\kappa_{i j}, \alpha\right) / \partial \alpha>0$. We can compare how education in community $i j$ does under decentralization relative to centralization by analyzing the trade-offs implied through comparative statics in the following expression:

$$
e_{i j}^{d}-e_{i j}^{c}=\frac{1}{2}\left[\theta_{i j} \hat{\gamma}_{i j}^{2} \lambda\left(\kappa_{i j}, \alpha\right)-N^{1-\phi}\right]
$$

where a positive number would mean that decentralization produces a better outcome. First of all, notice that all communities share the parameters $(\phi, N, \alpha)$, while the parameters $\left(\kappa_{i j}, \theta_{i j}, \hat{\gamma}_{i j}\right)$ are specific to each community $i j$, thereby generating heterogeneous effects.

A lower $\phi$ or a higher $N$ represent the economies of scale from providing education centrally. Both parameters increase the relative attractiveness of the centralized system, represented by the term $N^{1-\phi}$, whose effect is homogeneous across communities.

Decentralization brings decisions closer to the people, thereby alleviating information asymmetries (e.g. Oates, 1972). The benefits from decentralization are increasing in $\hat{\gamma}_{i j}$, which measures how "special" the needs of community $i j$ are. Through this channel, we would expect both the poorest and richest communities to benefit the most from 
decentralization given their largest distance from the median community in the country. Thus, this channel has an ambiguous effect on educational inequality across communities.

By bringing decisions closer to the people, decentralization also improves accountability and empowers participation of the local community, which is represented by a greater $\kappa_{i j}$ (since $\left.\partial \lambda\left(\kappa_{i j}, \alpha\right) / \partial \kappa_{i j}>0\right)$. Furthermore, this effect will be augmented by the degree of complementarity between government and community effort, which is represented by a higher $\alpha$ (since $\left.\partial \lambda\left(\kappa_{i j}, \alpha\right) / \partial \alpha>0\right)$. The effect of $\kappa_{i j}$ is highly heterogeneous across communities: it is likely that communities with higher physical and human capital will have a higher $\kappa_{i j}$, which will then magnify the effects of education. Indeed, the policy-makers can explicitly target these aspects of school autonomy (e.g. Pradhan et al, 2011).

There is only one parameter left to analyze: $\theta_{i j}>0$, which represents how local preferences for spending in education differ relative to the preferences of the central government. Remember we assumed $\theta_{i j}=1 \forall(i, j)$ under centralization. In the case of decentralization it could be one (as in centralization), or different than one. If $\theta_{i j}>1$, the local government gives relatively more importance to education than the central government. The interesting case is when under decentralization $\theta_{i j}<1$, which could have two possible interpretations.

On one hand, it could be that local governments have different preferences - e.g. they consider spending in health to be more important than in education. In this case, $\theta_{i j}<1$ would decrease the production of education under decentralization, but it would still increase social welfare as local governments are choosing a mix of spending closer to local needs (Faguet and Sanchez, 2006). Regarding inequality, all communities should experience an 
increase in welfare (and a decrease in education spending), relative to the centralized case; as a community's parameter gets further from 1, the greater are the community's gains.

On the other hand, $\theta_{i j}<1$ may indicate that local governments are more prone to be dominated by the local elite (Bardhan and Mookherjee, 2005 and 2006). In particular, this effect is more likely to appear in poor areas, where the institutions are weaker. As a consequence, this effect of decentralization is likely to exacerbate inequality in educational outcomes across communities. Indeed, there is some empirical evidence about how local governments can hurt local minorities (see Alesina et al, 2004 ${ }^{11}$ ).

In summary, the theoretical model raises the possibility of an equity-efficiency tradeoff from decentralization: even if decentralization had a large positive effect on the average community, it could be very prejudicial for poor communities or for communities with bad governance. Thus, in the empirical literature review that follows we will focus both on the average effect of decentralization and on the distribution of these effects across communities.

B. Review of the Empirical Literature. There are several strands in the empirical literature on decentralization. Firstly, there are cross-country studies that look at the regression of educational attainment on measures of school decentralization (and other control variables); they find positive correlation between student performance and decentralization (e.g. Woessmann $(2003)^{12}$ and PISA $\left.(2009)^{13}\right)$. Secondly, other papers report

\footnotetext{
${ }^{11}$ Alesina et al. use data on American school districts, school attendance areas, municipalities, and special districts, and find strong evidence that more heterogeneous populations (e.g. in terms of race, income) end up with more decentralized districts, thereby accentuating the inequalities in the local communities.

${ }^{12}$ Woessmann (2003) employs micro data on 39 countries and finds that student performance correlates positively with different decentralization variables (control mechanisms and exams, school autonomy in personnel, process decisions, and the influence of teachers on teaching methods).
} 
positive results from decentralization using a before-and-after-reforms analysis. For example, Faguet and Sanchez (2006) show that in Bolivia the priorities of local governments changed after decentralization, redirecting more investment towards education, and in Colombia decentralization of education finance improved enrollment rates in public schools. In addition to this, other studies have compared schools that changed autonomy levels with schools that did not. Jimenez and Sawada $(1999,2003)$ study the impact of EDUCO program (Education with Community Participation) in El Salvador, which was designed to expand education to isolated rural areas by decentralizing education through the direct involvement and participation of parents and community groups. They find that the program did not have a significant effect on math and language tests, but did have a positive effect on students' attendance and probability of continuing in school. ${ }^{14}$

Many authors have studied the decentralization process in Brazil. Madeira (2007) exploits longitudinal data on primary schools to evaluate the effects of the decentralization reform in Sao Paulo. He finds that decentralization increased dropout rates and failure rates across all primary school grades but improved several school resources, like the number of

\footnotetext{
${ }^{13}$ PISA 2009 suggested that the prevalence of schools' autonomy to define and elaborate their curricula and assessments relates positively to the performance of school systems, even after accounting for national income (PISA, 2009).

${ }^{14}$ In a similar spirit, King and Özler (2005) provide an impact evaluation of Nicaragua's school autonomy reform that started in 1993 and consisted in giving legal status and several key management tasks to school councils. The results indicate that autonomy de jure does not affect student's performance. However, higher de facto autonomy in some administrative decisions, especially in the ability to hire and fire school personnel, is correlated with higher student achievement.
} 
VCRs and TVs per hundred students, and increased enrollment. ${ }^{15}$ The author notes that the results are partially driven by the democratization of school access. Paes de Barros and Mendoça (1998) distinguish between three processes in Brazilian's decentralization during the 1980's: direct transfer of funds to schools, election of principals, and the creation of local school councils. They find positive but modest results of decentralization and an increase in inequality, since committees in low-income areas where less prone to be involved in school management.

However, the identification strategy of the above-mentioned papers does not allow one to rigorously assess the causal impact of decentralization on educational outcomes. This is mainly due to a potential selection bias when the decentralization/program assignment rule is not exogenous or because there are other, unobservable changes that are contemporaneous with the decentralization process, which may confound estimates of the effects of decentralization. Indeed, there seems to be evidence of the presence of differences in unobservable characteristics related to decentralization across groups: Gunnarsson et al. (2009) report that school autonomy and parental participation vary more within countries than between countries, which suggests that the decision of local communities to exercise their autonomy is probably endogenous.

To overcome these potential problems, Galiani et al. (2008) rely on a quasiexperimental design to exploit exogenous variability in school decentralization. That can provide a plausibly credible identification of the causal effect of decentralization on educational attainment. They take advantage of a decentralization reform in Argentina, where two systems of secondary schools - one administered by the provinces and the other by the

\footnotetext{
${ }^{15}$ Furthermore, he reports that the negative effects from decentralization were greater in the poorest communities.
} 
central government - existed side by side in the same communities for over a century. Between 1992 and 1994, the central government transferred all its secondary schools to provincial control. ${ }^{16}$ The authors use the exogenous variation in the jurisdiction of administration of secondary schools generated by this policy intervention to identify the causal effect of school decentralization on educational outcomes. They employ a dataset containing information for the period 1994-1999 on 3,456 public schools, accounting for 99\% of all public secondary schools: 2,360 were always provincial and 1,096 were transferred from the national to the provincial government between 1992 and 1994. Specifically, they compare changes in student outcomes at different lengths of exposure to decentralization to changes in outcomes of students in schools that were always under provincial control.

Galiani et al (2008) find that decentralization had an overall positive effect on student test scores: math test scores increased by $3.5 \%$ and Spanish test scores rose by $5.4 \%$, on average after 5 years of decentralized administration. However, the gains were exclusively in schools located in non-poor municipalities. In fact, in their most robust results -including province-year fixed effects- they report that decentralization did not improve average test scores in schools located in poor municipalities.

Finally, to date there is scarce experimental evidence of decentralization reforms. To the best of our knowledge, the available experimental evidence is based on programs that employed a different notion of decentralization than the one implied in the reported nonexperimental and quasi-experimental settings reviewed previously. For example, Benveniste

\footnotetext{
${ }^{16}$ The decentralization law did not change the distribution of resources among provinces. It also guaranteed that the provinces would not have to bear additional financial burden by taking on the operation of the transferred schools.
} 
and Marshall (2004) randomized locally managed grants for schools ${ }^{17}$ in Cambodia with positive average results. And Lassibile et al (2010) study workflow-enhancing interventions in Madagascar, showing positive average impacts of these interventions. ${ }^{18}$

In summary, most of the studies with a credible identification strategy suggest that there are positive average effects from different types of decentralization reforms (see Table 1). However, we should note that the effects of decentralization reforms depend on many country-specific features such as the political regime, power of local governments and commitment of the central administration to transfer funds, among others. Consequently the generalization of these results is problematic without understanding the underlying structural mechanisms at work.

\section{[Table 1 about here.]}

As far as the distributional effects are concerned, those papers that study impacts across groups tend to find that poor communities fail to gain from decentralization reform, which in turn increases inequality. There is also evidence in the developed world that richer

17 In the same line, Chaudhury and Parajuli (2010) study the Community School Support Project that randomized schools to an advocacy campaign and gave them a grant. Short run estimates show a significant impact on certain schooling outcomes (improvement in out of school children, repetition and equity, in the sense that disadvantaged castes perform better), although there is no evidence of improved learning outcomes.

18 The interventions at the school level, reinforced by interventions at the subdistrict and district levels, improved school attendance, reduced grade repetition, and raised test scores (particularly in Malagasy and mathematics), although the gains in learning at the end of the evaluation period were not always statistically significant. Interventions limited to the subdistrict and district levels proved largely ineffective.

Glewwe, Chapter 6, p.19 
regions benefit relatively more from decentralization, though the poorer also experience net gains. $^{19}$

We consider that it is of first order importance to disentangle the channels through which decentralization reform affects communities in order to help those that do not benefit from it. Following the stylized model, there could be different explanations such as the presence of powerful local elites that may impose their own needs, or parents that may not know how to collaborate in the production of education. If we can identify the specific reasons for the failure of decentralization reform in poor communities, then we will be able to design complementary interventions to make the most out of decentralization.

\section{Tracking}

The concept of tracking refers to a way in which students of the same cohort are allocated into classes: i.e., by tracking students by prior achievement and assigning the best half to one class and the weaker half to another class. Tracking is a controversial policy: on the one hand, by grouping students in more homogeneous groups teachers find it easier to target their teaching to the students, which improves educational outcomes; but on the other hand, if students benefit from better peers, tracking could impose serious disadvantages on low-achieving students by pooling them with worse students. Therefore, tracking - like decentralization - implies a trade-off between equity and efficiency. Also, teachers can also react by changing the way they teach because of tracking, such as targeting to the best or to median students.

\footnotetext{
${ }^{19}$ See Salinas and Sole-Olle (2009) for a study of the Spanish decentralization process in 1978-2005, or Barankay and Lockwood (2007) for an analysis of decentralization in the Swiss cantons.
} 
A. A Model of Tracking. Before stepping into the empirical literature, in the spirit of Duflo et al. (2011), we first present a stylized model to illustrate this trade-off. Denote $\theta_{i j}$ to be the uni-dimensional skill level for student $i$ in class $j$, which is a continuous variable with support $[\underline{\theta}, \bar{\theta}]$. The teacher can "target" a single ability level: e.g. he or she can focus on teaching the least gifted students, the median student, or the most gifted students. Let $T_{i j} \in[\underline{\theta}, \bar{\theta}]$ denote the ability level chosen by the teacher as a target. The cost for student $i$ in class $j$ from being in the class is greater the more distant the student's $\theta_{i j}$ is from $T_{i j}$. Because the teacher wants to maximize the educational outcomes, his problem is conceptually equivalent to the Hotelling problem of horizontal differentiation with a Social Planner.

The selection of $T_{i j}$ depends on the distribution of skills in the class. Figures 1a and $1 \mathrm{~b}$ show two different distributions of skills within a class. In Figure 1a the distribution of skills is uni-modal, so the teacher will likely choose $T_{i j}$ equal to the mode of the distribution. In Figure $1 \mathrm{~b}$ the distribution of skills is bi-modal, so the choice of $T_{i j}$ is likely to be either at one of the modes or in the middle of the two modes, depending on the convexity of the cost function of the students and on how much the teacher values equity vs. efficiency. The benefits from tracking will be higher if skills are distributed like in Figure $1 \mathrm{~b}$ rather than in Figure 1a.

[Figure 1 about here.]

However, tracking may lead to greater inequality if there are peer effects in the classroom. Indeed, there is empirical evidence about the importance of intra-class peer effects 
(see for example Jackson (2010), Zimmerman (2003), Ding and Lehrer (2006) or Burke and Sass (2008)).

We have to take into account that peer effects can substantially change the distribution of tracking effects. Let $N_{\mathrm{j}}$ be class $j$ 's size. Students choose study effort, $e_{i j}$. The educational outcome, $y_{i j}$, is not only a function of own effort and type, but also a function of the efforts and types of the other students inside the classroom, $\eta_{\mathrm{ij}}$. One possible functional form could be:

$$
y_{i j}=\theta_{i j} e_{i j} \mathrm{~g}\left(\eta_{\mathrm{ij}}\right) \text {, with } \eta_{\mathrm{ij}}=\frac{1}{\mathrm{~N}_{\mathrm{j}}-1} \sum_{\mathrm{k} \neq \mathrm{i}} \theta_{k j} e_{k j},
$$

where $\mathrm{g}(\cdot)$ is an increasing function that takes positive values, which represents the complementarity between own effective effort (and type) and peers' effort (and type). Peer effects work through two channels. Firstly, tracking has direct peer effects because it changes the composition of skills in the classroom, so every student faces peers with a different composition of skills. Secondly, tracking has indirect peer effects, because the students adapt to each other's effort. ${ }^{20}$

To clarify the effects of tracking, imagine that we take two identical groups of students and we do the following experiment: we take the least-skilled student from group 1 and swap it with the most skilled student from group 2. Both groups now have more homogenous skills, so on average the teacher can better target the teaching style: i.e. $T_{\mathrm{ij}}$ will go up (down) in group 1 (2).

\footnotetext{
${ }^{20}$ Note that, depending on the equilibrium concept that one uses, students may not fully internalize the social benefits from making an effort and thus under-provide effort relative to the social optimum. However, this feature is not critical for the results that follow.
}

Glewwe, Chapter 6, p.22 
We can see what will happen with students in both groups. Most students in group 1 will be closer to the teacher's target, and therefore they will increase their effort, $e_{i j}$. They will also benefit directly from having better peers, and from the reinforced effort through the peer effects, $\mathrm{g}\left(\eta_{\mathrm{ij}}\right)$. Thus, the welfare of most students in this group is expected to rise. Nevertheless, the least skilled students in group 1 might actually become slightly further away from the teaching target. Even in this case, they will benefit in net terms because they gain from having better peers and from their peers' higher effort (through the reinforced learning, $\left.\mathrm{g}\left(\eta_{\mathrm{ij}}\right)\right)$. In group 2 everyone will face a negative direct effect because of having less skilled peers, through $\mathrm{g}\left(\eta_{\mathrm{ij}}\right)$. Since the group is more homogeneous, most students get closer to the teacher's target, which is beneficial (although the most skilled students in the group can become further away from the target). Thus, the net effect on the welfare of the members of group 2 will depend upon the importance of the magnitude of the peer effects, $g(\cdot)$, relative to the potential gains from better teacher targeting.

The tracking intervention consists of repeating the above intervention until we reach two non-overlapping groups of students. If there are no peer effects, then the net effect from tracking will be positive for everyone except for the students that were originally near the median skill (who became actually further away from the teaching target). The effect on inequality would be ambiguous, depending on whether the top individuals in the higher class benefit more than the bottom individuals in the lower class.

But if peer effects are significant, then anything can happen. If peer effects mean mainly that students' efforts are very complementary, then every student may benefit in net terms, as the students that benefited from better targeting will exert a higher effort and thus benefit the students who face negative direct effects (i.e. those with worse targeting and/or 
worse peers). However, if the direct benefits from better targeting are small relative to the direct negative effect of having worse peers, then most students in the lower class will be worse off with tracking while most students in the higher class will be better off with tracking. As a consequence, sizeable peer effects can induce an efficiency-equity trade-off.

B. Review of the Empirical Literature. Table 2 summarizes the main findings of the studies that have analyzed tracking interventions. The most elementary empirical strategy to assess the effects from tracking consists of comparing students in tracking and nontracking schools. The earlier empirical estimations seemed to suggest that although tracking was beneficial for the high-skilled students, it ended up hurting the low-skilled students, thus augmenting inequality (see for instance Kerckhoff (1986), Hoffer (1992) and Argys et al (1996)). In particular, the PISA 2009 Assessment Framework was very critical of tracking programs because of the possibility that they increase the differences across students while not improving overall performance. ${ }^{21}$ Exploiting a more elaborated strategy, Hanushek and Woessmann (2006) also look at country-level differences, but using students of different cohorts to get a difference-in-difference estimate. They still find that early tracking substantially increases educational inequality and they also argue that early tracking reduces mean performance.

\footnotetext{
21 "School systems that seek to cater to different students' needs through a high level of differentiation in the institutions, grade levels and classes have not succeeded in producing superior overall results, and in some respects they have lower-than-average and more socially unequal performance. ... In countries where 15-yearolds are divided into more tracks based on their abilities, overall performance is not enhanced, and the younger the age at which selection for such tracks first occurs, the greater the differences in student performance, $\ldots$ without improved overall performance.” (PISA, 2009; p. 15)
} 
[Table 2 about here.]

Betts and Shkolnik (2000) provide a good summary of the non-experimental literature, and argue that the existing consensus against tracking was largely based on invalid comparisons. Intuitively, most of the papers they review compare the top students or the bottom students in tracking schools to the average students in non-tracking schools. ${ }^{22}$ Indeed, Betts and Shkolnik (2000) show that when students of similar ability levels in tracking and non-tracking high schools are compared, the findings are strikingly different: high-ability students benefit from tracking, low-ability students neither benefit nor get hurt, although there is some evidence that middle scoring students may be hurt ${ }^{23}$ (see also Figlio and Page (2002)).

However, the decisions to work/enroll in tracking/non-tracking schools by teachers and parents/students might be endogenous. Ideally we would like to have experimental or quasi-experimental evidence on tracking programs to avoid this potential problem. Fortunately, there is one paper with experimental evidence that provides a credible identification strategy for the effect of tracking on students' performance.

Duflo et al. (2011) performed a randomized controlled trial to study the effects of tracking in Kenya. In 121 schools that used to have a single first-grade class, that grade was

\footnotetext{
${ }^{22}$ In a similar spirit, Manning and Pischke (2006) show that controlling for baseline scores is not sufficient to eliminate the selection bias when comparing students attending comprehensive versus selective schools in the United Kingdom.

${ }^{23}$ The fact that middle scoring students are the group that benefits least from tracking is consistent with the model presented, when they are the only ones getting further away from the teacher target after the tracking intervention.
} 
split into two sections. In 60 schools, randomly selected out of the 121, students were assigned to sections based on prior achievement as measured by first term grades, assigning the top and bottom halves to different sections. In the remaining 61 schools, students were randomly assigned to one of the two sections. The findings are very encouraging for supporters of tracking: students in tracking schools scored on average 0.14 standard deviations higher than students in non-tracking schools at the end of the program (18 months later); students at all levels of the distribution benefited from tracking, and this effect persisted one year after the program ended.

Regarding the direct and indirect peer effects discussed above, the authors find that while the direct effect of high-achieving peers is positive, tracking benefited lower-achieving pupils indirectly by allowing teachers to teach at their level. Together, these results show that peers affect students both directly and indirectly by influencing teacher behavior, in particular by influencing the teacher's effort and choice of target teaching level (closer to the median student). ${ }^{24}$ Therefore, these findings suggest that there is a substantial chance that tracking could be a beneficial policy.

Tracking is particularly attractive because the intervention is standardized; the only need for its implementation is to change the rule by which students are grouped into classes. In contrast, the details of school decentralization usually depend on many characteristics of the country (the size of the country, the power of local elites, etc.).

Nevertheless, there are some concerns regarding the external validity of this experiment that should be taken into account. For instance, as Duflo et al. (2011) point out, the behavior of teachers is crucial for the results: if the policy is generalized, teachers may

\footnotetext{
${ }^{24}$ This happens in a context in which teachers have convex payoffs in student test scores.
} 
sort to the higher or lower level sections of the classes (see also Pop-Eleches and Urquiola, 2011). They also emphasize that in the experiment many key factors that could affect the results were left unchanged, such as the resources for the classes and the class size. It could be the case, however, that in a scaling-up process, the resources would not be split evenly between classes. For example resources may be allocated to help the worse-achievers to catch up.

Furthermore, it might be that the degree of peer effects may change if the experiment is performed in higher grades (instead of 1 st and $2 \mathrm{nd}$ ), because the effects may be stronger in older children (e.g. they compete for status, they collaborate in homework). Also, there are some cultural and socio-economic factors that may change the results in other countries, because they may affect the initial distribution of students. For instance, in very poor communities there are many students with special needs (e.g. suffering from domestic violence, malnutrition), so the problem of the teacher may look more like Figure 1b, with the low mode of students being those with special needs. On the contrary, in not-so-poor communities the students' needs may be substantially more homogenous, thereby reducing the potential targeting-benefits from tracking. Duflo et al. (2011) make a similar point, arguing that their results are more likely to be found in sub-Saharan Africa and South Asian countries, rather than in the U.S. Hopefully, further experimental evidence will contribute to our understanding of the key assumptions to ensure the external validity of these findings.

\section{Teacher Incentives}

The role of compensation policy in influencing worker performance has been extensively analyzed in the theoretical and empirical literature. In this section we analyze different compensation and incentive-based policies. Of particular interest in the recent 
empirical literature are the effects that compensation policies have on worker productivity, often referred to as "incentive effects". More specifically, we are interested in whether paying teachers on the basis of their students' performance induces them to improve the overall quality of teaching and hence increases student learning.

Mostly, teachers are paid according to observable characteristics, like educational background, experience or tenure. However, those measures are usually poor predictors of better student outcomes (see, among others, Rivkin et al. (2005)). The idea behind paying teachers on the basis of direct measures of their students' performance is that this provides them an incentive to improve the quality of their teaching and thereby increase their students' learning.

A. Theoretical Framework. In this section we discuss interventions that introduce pay-for-performance incentives. We adapt the model in Franceschelli et al. (2008) on compensation in firms to a school setting in order to formalize two probable consequences from the introduction of pay-for-performance interventions: i) it might increase the effort (outcomes) of both high- and low-productivity teachers; ii) it might also increase the turnover among low-productivity teachers.

Teachers' utility depends positively on income, T, and negatively on effort, $\mathrm{X}$ : $\mathrm{u}(\mathrm{T}, \mathrm{X})$, with $\mathrm{u}_{\mathrm{T}}^{\prime}\left(\mathrm{)}>0\right.$ and $\mathrm{u}_{\mathrm{X}}(\mathrm{)})<0$. A teacher's output is given by the performance of the students, q, which depends on the teacher's level of ability, A, and his or her effort, X: q = $\mathrm{f}(\mathrm{X}, \mathrm{A})$ with $\partial \mathrm{f}(\mathrm{g} / \partial \mathrm{X})>0$ and $\partial \mathrm{f}(\mathrm{)} / \partial \mathrm{A})>0$. If a teacher is fired, he or she will receive a compensation equal to $\mathrm{Z}$, and if the teacher is not fired, he or she will receive a wage $\mathrm{W}=\mathrm{Y}$ $+b(q)>Z$ (note that the wage may depend upon the teacher's performance). 
The probability of a teacher being fired is given by: 1 if ${\mathrm{q}<\mathrm{q}_{0}}_{0} ; \delta(q)=\frac{q_{1}-q}{q_{1}-q_{0}}$ if $\mathrm{q}_{0} \leq \mathrm{q}<\mathrm{q}_{1}$ and 0 if $\mathrm{q}_{1} \leq q$. That is, the teacher will be fired with probability one if her students do not achieve an average score of at least $q_{0}$; if $q$ is between $q_{0}$ and $q_{1}$ then the probability that a teacher will be fired is linearly decreasing on the level of performance of her students; and if the average performance of the students surpasses the threshold $q_{1}$ then the probability of being fired is zero. Recall that the teacher's wage, if she is not fired, is given by $\mathrm{W}=\mathrm{Y}+\mathrm{b}(\mathrm{q})$. There are two possible wage schedules. Under the flat wage scheme, $b(q)=0$ for every $q$ (i.e. an hourly wage). Under the pay per performance scheme $b(q)=0$ if $\mathrm{q} \leq q_{1}$ and $\mathrm{b}(\mathrm{q})=\mathrm{b}^{*}\left(\mathrm{q}-q_{1}\right)$ if $\mathrm{q}>q_{1}$. In sum, the employer (schools) sets three key parameters: $\Omega=\left\{\mathrm{q}_{0}, \mathrm{q}_{1}, \mathrm{~b}\right\}$.

We define $\mathrm{q}^{*}(\mathrm{~A})$ as the Nash equilibrium solution to this problem. It can be shown that, under the hourly-wage system, $\mathrm{q}^{*}(\mathrm{~A})$ is an increasing function of $\mathrm{A}$ under the basicwage scheme (Proposition 1 in Franceschelli et al., 2008). Intuitively, higher-ability teachers will display a better performance because by doing so they can reduce their chances of being fired. However, note that if the probability of being fired is negligible or even null as a function of the students' performance - as it is often the case for school teachers in developing countries - then teachers will exert very low, if any effort.

It can also be shown that under the pay-for-performance scheme there will be a cutoff level $\mathrm{A}^{*}$ such that if $\mathrm{A}>\mathrm{A}$ *, then the teacher will decide to produce in the piece-rate segment and if $\mathrm{A}<\mathrm{A}^{*}$, the teacher will decide to produce in the basic wage segment when offered the option (Proposition 2 in Franceschelli et al., 2008). We will refer to "low-ability" teachers as those with $\mathrm{A}<\mathrm{A}^{*}$ and to "high-ability" teachers as those with $\mathrm{A}>\mathrm{A}$ *. 
Proposition 3 in Franceschelli et al. (2008) analyzes the dynamics when the system changes from a flat wage regime to a pay-for-performance scheme. They show that both low and high-ability teachers will raise their output levels, but for different reasons: low-ability teachers will raise their output because of the stricter endogenous dismissal policy and highability teachers will increase their output in response to the introduction of the piece-rate component in the wage scheme. Thus, the channel of the incentive effect is different for those workers seeking the basic wage and those workers seeking the piece-rate component of the wage. Finally, Franceschelli et al. (2008) show that - at least under certain parametric assumptions - a rise in the turnover rate for low-ability teachers is expected after the implementation of the piece-rate with a basic wage.

Franceschelli et al. (2010) test the predictions of this model in a quasi-experimental setting when a textile firm decided to shift one of its plants to a piece-rate plus basic wage scheme while the other plant continued to be paid on an hourly basis. Using longitudinal data on worker productivity in the two plants before and after the first plant changed its payment scheme, they find that the implementation of the pay per performance system had a strong positive effect on productivity ( 28 percent, on average) and that many workers continued to receive the basic wage after the changeover to the new incentive scheme. The effect of treatment was a 29 percent increase in the average productivity of workers aiming at the basic wage and a 26 percent increase for workers seeking the piece-rate component of the wage. Thus, the evidence presented in the paper suggests that the change in the incentive scheme made, endogenously, the dismissal policy of the firm stricter, inducing even low-ability workers to increase their productivity.

B. Review of the Empirical Literature. The main obstacle in assessing incentive effects empirically is the endogeneity of contractual arrangements. There are some recent 
papers, however, that analyze the effect of different compensation schemes for teachers using experiments to induce exogenous changes in the compensation schemes (see Table 3 for a summary). Nevertheless, they find mixed results.

\section{[Table 3 about here.]}

Muralidharan and Sundararaman (2011) provide evidence from a large-scale randomized evaluation of a teacher performance pay program implemented in 300 public schools in the Indian state of Andhra Pradesh. They study the effect of a teacher performance pay (a bonus calibrated to be around 3 percent of a typical teacher's annual salary). ${ }^{25}$ They randomly selected 100 schools to implement performance pay at the teacher level, randomly selected another 100 schools to implement it at the school level, with the remaining 100 randomly chosen schools serving as the control group. They find that the teacher performance pay program was effective in improving student learning: at the end of two years of the program, students in the 200 schools with incentive systems performed significantly better than those in comparison schools by 0.27 and 0.17 standard deviations (SD) in the mathematics and language tests, respectively. ${ }^{26}$ They found a minimum average treatment effect of $0.1 \mathrm{SD}$ at every percentile of the distribution of baseline test scores, suggesting broad-based gains in test scores as a result of paying teachers based on their students' performance.

\footnotetext{
${ }^{25}$ The authors studied two types of teacher performance pay (group bonuses based on school average performance and bonuses paid to teachers based on their individual performance).

${ }^{26}$ School-level group incentives and teacher-level individual incentives performed equally well in the first year, but the individual incentive schools outperformed the group incentive schools after 2 years of the program.
}

Glewwe, Chapter 6, p.31 
The authors find no evidence of any adverse consequences as a result of the incentive programs. Students in incentive schools did significantly better not only in mathematics and language (for which there were incentives) but also in science and social studies (for which there were no incentives), suggesting positive spillover effects. The suggested channel through which the impact of the incentive scheme operates is not an increase of teacher attendance but greater teaching effort conditional on being present: teacher interviews indicate that teachers in incentive schools were more likely to have exerted extra effort such as assigning additional homework and class work, providing practice tests, and conducting extra classes after school.

The authors of this study also compare this intervention to other interventions of similar costs that consisted of additional schooling inputs. The resource-based interventions were also effective in raising test scores, but the teacher incentive program was three times as cost effective in raising test scores.

Regarding the effect of this intervention on the distribution of test scores, the authors find that the quantile treatment effects of the treatment are positive at every percentile and increasing. However, the program also increased the variance of test scores. The authors claim that this may reflect variance in teacher responsiveness to the incentive program, as opposed to variance in student responsiveness to the treatment by initial learning levels. Lastly, the authors cannot study the effects on turnover because the experiment was designed so that turnover is almost ruled out (there was an agreement with the government to minimize transfers into and out of the sample schools for the duration of the study).

Another source of experimental evidence for a developing country is Glewwe et al. (2010). The authors report results from a randomized evaluation that provided primary school teachers (grades 4-8) in rural Kenya with group incentives based on test scores. They found 
that while test scores went up in program schools in the short run, the students did not retain the gains after the incentive program ended. Furthermore, teacher attendance did not improve, homework assignments did not increase, and pedagogy did not change, although teachers did increase their effort to raise short-run test scores by conducting more test preparation sessions. The authors of this study interpret these results as being consistent with teachers expending effort toward short-term increases in test scores but not toward long-term learning. ${ }^{27}$

Finally, Duflo et al. (forthcoming) provide a valuable step in the direction of understanding incentives for teachers by combining experimental variation with the structural estimation of a model. They worked with single-teacher non-formal education centers in the rural villages of Rajasthan, India, where an NGO gave teachers in 57 randomly selected program schools a camera with a tamper-proof date and time function, to check attendance of teachers. Each teacher was then paid according to a nonlinear function of the number of valid school days for which they were actually present. The other 56 schools were randomly allocated to the control group. The reduced-form results of the program were positive: absenteeism by teachers fell by 21 percentage points relative to the control group. Teacher attendance increased for both low and high quality teachers (those scoring below and above the median test scores on the teacher skills exam conducted prior to the program) ${ }^{28}$ Children in the program schools had more teaching days and, conditional on the school being open,

\footnotetext{
${ }^{27}$ The program was designed to offer prizes only to teachers who were already employed before the program to avoid that the entry and exit rates of teachers would be altered by the introduction of the incentives scheme.

${ }^{28}$ The program impact on attendance was larger for below median teachers (a 24 percentage point increase versus a 15 percentage point increase for above median teachers). However, this was due to the fact that the program brought below median teachers to the same level of attendance as above median teachers (78 percent).
} 
teachers were found teaching during random visits (thus, the authors did not find evidence of multitasking or loss of intrinsic motivation due to the program). As a consequence of more instruction days with no apparent reduction of teacher effort, children's test scores increased by 0.17 standard deviations in treatment schools. ${ }^{29}$ Children who could write at the time of the pre-test gained the most from the program (they had mid-line test scores 0.25 standard deviations higher in treatment schools than in comparison schools), suggesting that those more advanced before the program were better equipped to benefit from it.

The authors complement these results with the estimation of a structural dynamic model of teacher labor supply to understand which component of the program affected the behavior of the teachers (monitoring or financial incentives) and assess the effect of other payment structures. They find that teachers are responsive to the financial incentives: the elasticity of labor supply with respect to the level of the financial bonus is between 0.20 and 0.30 and, when the bonus is set to zero, the model closely predicts the difference in attendance between teachers in the treatment and control schools.

C. Contract Teachers. In recent decades there has been a sharp increase in student enrollment in developing countries. One way to bring them into the education system without prohibitively expensive increases in the teacher salary budget is to arrange for local hiring of teachers on short-term contracts. We refer to the teachers under these contracts as "Contract Teachers" (De Laat and Vegas, 2005). In most of these large-scale teacher recruitment

\footnotetext{
${ }^{29}$ Over the 30 months in which attendance was tracked, the treatment reduced teacher's absenteeism rates $(42 \%$ in control group vs. $22 \%$ in treatment group), increased student's test scores (by 0.17 standard deviations) and raised the probability of students being accepted into regular schools (by $40 \%$ ).
}

Glewwe, Chapter 6, p.34 
programs the teachers are not employed in civil servant positions, they receive considerably lower salaries, have less tenure and usually significantly less professional training. ${ }^{30}$

This policy is highly controversial. In spite of this, some economists and policymakers believe that increasing the use of contract teachers may have been one of the most efficient innovations in providing primary education in developing countries. The benefit most cited in the literature is that contract teachers face superior incentives compared to tenured civil-service teachers: they must work hard to build a reputation and eventually receive another appointment or even a civil servant position. Civil-service teacher positions are highly demanded in some countries because hiring and supervision is centrally conducted and salaries are much higher than the salaries necessary to clear the market. Because contract teachers are locally hired, it is possible that this may reduce their absenteeism through closer monitoring and better target the needs of their students - advantages associated to decentralization reform.

At the same time, many arguments have been raised against contract teacher programs. Contracted teachers usually have less teaching experience and, due to their shortterm contracts, they cannot get involved in following the progress of their students. Some authors also worry that the extrinsic incentives may crowd out the teacher's intrinsic motivation to exert teaching effort (Benabou and Tirole, 2006). In a related note, providing incentives for some outcomes may end up perversely distorting the allocation of effort (Holmstrom and Milgrom, 1991), as illustrated by Glewwe et al. (2010). Also, one may worry that contract teachers may de-professionalize teaching and thus impoverish the status of teaching as a profession (e.g. Bennell, 2004).

\footnotetext{
${ }^{30}$ See Duthilleul (2005) for a review of contract teacher programs in several countries.
} 
Table 3 summarizes the main findings of the studies analyzing this intervention. Some papers exploit non-experimental data to study the relative performance of contract teachers. For example, De Laat and Vegas (2005) compare the performance of contract teachers' students with other students in Togo, Bourdon et al. (2006) study contract teachers in Niger, and Bourdon et al. (2007) examine contract teachers in Niger, Mali, and Togo. The findings are mixed. On one hand, the findings of De Laat and Vegas (2005) suggest that students of regular teachers clearly outperform those of contract teachers, and Bourdon et al. (2006) argue that contract teachers may deteriorate education quality. On the other hand, Bourdon et al. (2007) suggest that contract teachers may have a positive impact, although they do find negative impacts when it is implemented in a more centralized manner. In addition to these studies, Goyal and Pandey (2009) report that contract teachers consistently demonstrated higher effort than regular teachers. In addition, in the Indian states they studied contract teachers were actually more educated than regular teachers. Finally, Kremer et al. (2005) report that contract teachers appear to have a rate of absenteeism similar to that of regular teachers. Likewise, Chaudhury et al. (2006) report that contract teachers in five countries are no less likely to be absent than other teachers (but not in a sixth country).

From the perspective of identification, comparing students with contract teachers to those with regular teachers can be misleading if, for example, the areas with the poorest educational outcomes may be more likely to hire contract teachers, generating a spurious negative correlation between contract teachers and student performance. Fortunately, there is an emerging literature exploiting experimental variation in the use of contract teachers. Contrary to the mixed results of the non-experimental studies, the experimental results suggest that contract teachers tend to have positive results. 
The first experimental evidence comes from the Kenyan Extra Teacher Program (Duflo et al., 2007). ${ }^{31}$ The 210 schools in the program were randomly assigned to two groups: 140 treatment (or "ETP”) schools and 70 comparison schools. In 70 of the 140 treatment schools, first grade pupils were randomly assigned to either a newly hired contract teacher or a regular, civil service teacher. Those contract teachers had the same academic qualifications as regular teachers but were paid less than one fourth as much as the regular teachers. In treated schools, they were roughly 16 percentage points more likely to be in class and teaching than civil service teachers in comparison schools. Students assigned to contracted teachers scored 0.23 standard deviations higher and attended school 2 percent more often than students who had been randomly assigned to civil service teachers in program schools. Moreover, students of contract teachers were 5.5 percentage points more likely to have reached third grade in 2007 than students in treatment schools taught by civil service teachers.

Similar results are reported by Muralidharan and Sundararaman (2010), who analyze a contract teacher program conducted in India, where 100 randomly-chosen government-run rural primary schools in Andhra Pradesh were provided with an extra contract teachers. After two years, students in schools with an extra contract teacher performed significantly better on academic tests than those in comparison schools, by 0.15 and 0.13 standard deviations on mathematics and language tests, respectively. While all students benefited from the program, the extra contract teacher was particularly beneficial for students in their first year of school and students in remote schools. However, these results might also be driven by the reduction in class size that resulted of adding a teacher. The authors also find, using four different nonexperimental estimation procedures, that contract teachers are no less effective in improving

\footnotetext{
${ }^{31}$ See also Duflo, Dupas and Kremer (2011).
} 
student learning than regular teachers who are more qualified, better trained, and paid a five times higher salary. Furthermore, contract teachers were significantly less likely to be absent from school than civil-service teachers (16\% vs. 27\%). Finally, Banerjee and Duflo (2011) review other programs that provide indirect experimental evidence about the benefits of locally-hired teachers (or volunteers) to help the more disadvantaged students. ${ }^{32}$ For example, in a remedial education program reviewed, which hired young women to teach students lagging behind in India, they find that the intervention increased average test scores for all children in treatment schools by 0.28 standard deviations, mostly due to large gains experienced by children at the bottom of the test-score distribution.

A key goal for future research would be to disentangle the channel through which this better performance of contract teachers works. Some argue that the increase in performance is related to the fact that contract teachers perceive their temporary positions as a probation period to obtain a civil service position. For example, in the area of Kenya where the experiment by Duflo et al. (2007) was performed, $32 \%$ of the contract teachers in the program eventually obtained a civil service position. Also, in West African countries teachers' unions have made the extension of job stability to contract teachers a political goal (Bruns et al., 2011). If it is inevitable that contract teachers will become civil servants, then we need to study whether their behavior, once they are upgraded, differs from the behavior of the teachers that started their careers as civil servants. If they do not differ, then a contract

\footnotetext{
${ }^{32}$ They report the results of the remedial education program in India (Banerjee et al., 2007), which hired young women to teach students that lagged behind in basic literacy and numeric skills, with positive results. Likewise, Banerjee et al. (2008) study a reading intervention in rural India that trained community volunteers who had a tenth- or twelfth-grade education for four days to teach children how to read, which significantly improved reading achievement.
} 
teacher system can be viewed as a successful probation mechanism (see Gordon et al, 2006), but one with effects that do not persist after teachers become civil servants.

Many of the papers advocating for contract teachers claim that the benefits arise mostly from the provision of better incentives. If this is the case, it is necessary to find the best way to provide incentives to teachers so that they engender long-lasting improvements in student learning. It is possible that this could be achieved through contract teachers or by other pay for performance schemes. This should be further investigated. Those benefits from better incentives could then be extended to civil service teachers, for example, by teacher union agreements to reform the tenure of the teachers to depend on performance.

As mentioned above, another aspect of education management that is involved in contract teacher interventions is decentralization. While civil servant teachers are hired centrally - and they are supervised, promoted, and transferred in the same way - it is a local committee that is in charge of the contract teachers' appointments. It may be that contract teachers outperform tenured ones because of a better selection by the local committees, or because they are more aware of the needs of students living in their communities they can better target the needs of these children. If this is the case, decentralization of hiring and/or supervision could be enough to improve the performance of civil service teachers. In fact, Duflo et al. (2007) show that in the schools that had empowered committees to monitor teachers, civil service teachers were more likely to be in class and teaching during random visits, and their students performed better than in schools with unmonitored civil service teachers.

From the point of view of both researchers and policy-makers, the biggest identification challenge that contract teacher programs face for future research is to understand why contract teachers perform better. It is important to notice that if these 
programs are to be scaled-up we should also consider whether there would be equilibrium effects in terms of the subsequent distribution of teacher skills.

Most obvious of all, improved evidence about these topics is crucial to assess the external validity of contract teacher interventions. For example, the cost-effectiveness of a contract teacher policy is likely to depend on country characteristics and the level of education involved. The experimental studies mentioned above involve contract teachers only at the primary level, where the supply of potential teachers with minimum capacity is not as likely to be constrained as at the secondary level (Bruns et al., 2011). Also, cost-benefit evaluations will not only allow us to see whether contract teachers are preferable to regular teachers, but also to compare contract teachers to other related interventions (see Chapter 8 in this volume about cost-effectiveness of educational programs).

\section{Complementary Interventions}

When we evaluate public policies - or social programs of any kind - we usually consider the effects of the program on the welfare of the affected population; this is the Welfare Criteria (Kaplow and Shavell, 2002). An intervention that improves the welfare of at least one individual without making anyone worse-off is considered desirable; this is the Pareto Criteria. However, most policies cannot be ordered according to the Pareto Criteria. In democratic states, the preferences of the society as a whole should be taken into account to adopt reforms. This suggests that it is convenient to have a "social welfare function" through which the different alternative policies could be compared. In spite of this, a traditional result in welfare economics shows the impossibility of aggregating preferences of diverse agents in an acceptable way (Arrow, 1951). 
Leaving this difficulty aside, we may act as if there exists a "correct" way to represent the preferences of the society. In the literature, different welfare functions have been postulated, implying diverse trade-offs between the efficiency and equity objectives. Obviously, these issues are subjective, and thus controversial. Nevertheless, policy-makers must make policy choices continuously due to budget constraints or to cases where the alternatives are mutually exclusive. As far as the choice of policies is concerned, if we do not consider distributional issues in principle, cost-effectiveness analysis is the best criterion available. In spite of this, distributional conflicts are always present when deciding public policy interventions.

These considerations about welfare functions and the efficiency/equity trade-offs could be important in deciding whether a reform should be adopted. In the previous sections we reviewed different School Management interventions. Indeed, not only did we study the average effect of interventions, but also - when evidence was available - we analyzed their potential distributional effects. In the case of contract teachers there is little evidence about how heterogeneous the effects are, although some papers do report such interventions to be especially beneficial for the lowest-achieving students. ${ }^{33}$ Instead, in the case of teacher incentives, the evidence seems to go in the opposite direction, suggesting that the most able students tend to gain more from it. Even though decentralization seems to have average positive effects, the poor do not always benefit from this type of reform, and could even be harmed. Regarding tracking, the results are more heterogeneous: most non-experimental empirical studies report that tracking hurts the least-performing students, while the sole experimental study finds benefits for students at all skill levels.

\footnotetext{
${ }^{33}$ See Banerjee et al., 2008; Bourdon et al., 2007.
} 
When policies that are on average beneficial engender distributional effects, the efficiency equity trade-off that we mentioned above is usually crucial. ${ }^{34}$ Let's consider the following highly-stylized model. Assume that there are only two groups, rich and poor, in equal proportions, denoted by subscripts $r$ and $p$, respectively. There is one function mapping the common educational policy $E \in[E, \bar{E}]$ to the incomes of the rich, $Y_{r}(E)$, and the incomes of the poor, $Y_{p}(E)$. The typical efficiency-equity trade-off can be represented by a situation such as an increase in $E$ produces a growth in average income, $\frac{1}{2} Y_{r}(E)+\frac{1}{2} Y_{p}(E)$, but at the same time diminishes $Y_{p}(E)$. Suppose there is a redistributive mechanism that can be used to transfer an amount $T$ from rich to poor individuals. Of the income taken from the rich an amount $C(T)$ is lost, where the (increasing and convex) function $C(\cdot)$ represents the typical problems associated with distortive redistribution that are widely studied in Public Economics (e.g. moral hazard, distortion of relative prices, etc.). Let $U($.$) be the usual$ indirect utility function, strictly increasing and concave. The problem for the utilitarian government is:

$$
\max _{\{T, E \in[E, E]} U\left(Y_{r}(E)-T\right)+U\left(Y_{p}(E)+T-C(T)\right) \quad \text { s.t. } 0 \leq T \leq Y_{r}(E)
$$

After combining the FOCs for an interior solution, we get:

$$
\frac{Y_{p}^{\prime}\left(E^{*}\right)}{Y_{r}^{\prime}\left(E^{*}\right)}=C^{\prime}\left(T^{*}\right)-1
$$

On the left side, we have the ratio of marginal returns from education for the rich and the poor while on the right side we have the marginal cost from redistribution. Therefore, a

\footnotetext{
${ }^{34}$ Although in some cases redistribution is actually found to be efficient (Mookherjee, 2006), this trade-off is a commonplace in the models of economists and policy-makers.
} 
benevolent utilitarian government should use the marginal cost from redistribution as a rule to think about the equity-efficiency trade-off. In the developing world this marginal cost is usually high - certainly higher than in the developed world - due to a variety of welldocumented problems: widespread corruption, large informal sector, fiscal evasion, lack of trust, etc. (see, for example, Olken, 2006). This would imply that the optimal educational policies in the developing world should be relatively more oriented towards equity than in the developed world.

However, instead of dismissing interventions due to inequity concerns, the policymaker could exploit complementary interventions to improve the situation of those that are harmed by the policy (i.e., seek a second instrument to achieve this desirable second goal). For example, in the case of complementary interventions to apply together with decentralization, we should think of how the educational performance of the poor could improve. According to the literature, a key point to consider is that even the best school policies may have little or no effect when students and parents fail to respond with the right actions (see, for example, the model in Section III). A combination of lack of information and inaccurate expectations can leave the poor trapped in poverty, given that they are unable to adopt actions that would improve their living standards considerably (e.g. Banerjee and Duflo, 2011).

First, poor households may not have information about their potential returns from education. Thus, providing students/families with information - which is a relatively inexpensive policy - may push individuals towards better choices about human capital investment. Indeed, Jensen (2010) provided a random subset of schools with information on the returns to schooling (estimated from earnings data). Relative to those not provided with information, these students reported dramatically increased perceived returns when re- 
interviewed four to six months later, and on average completed 0.20 more years of schooling over the next four years. Nguyen (2008) also presents experimental data, in this case from Madagascar, which shows that informing fourth-grade students and their parents about the returns to schooling increased average daily attendance by 3.5 percentage points and test scores by 0.20 standard deviations after three months. And Dinkelman and Martinez (2011) show that giving/showing a DVD with information to high-school students in Chile increased attendance and willingness to finance future education with government loans. Perhaps if parents and students from poor households upgrade their perceived returns to schooling with this complementary intervention, then they will better exploit the advantages of school management reforms (for example, by attending parent meetings).

Second, parents in poorer areas might not have information about their rights, how to demand that they be respected, and how to help the school to improve their children's education. This problem is particularly important in the context of school decentralization. In the context of the model presented in Section III, the value of $\kappa_{i j}$, which represents the efficiency of community $i j$ 's effort, may need to be raised. The experimental evidence shows that there is scope for improvements of this type. Banerjee et al. (2008) study the Village Education Committees (VECs) program in India, which was supposed to monitor the performance of the schools, report problems to higher authorities, hire and fire communitybased teachers, and use additional resources for school improvement from a national education program. ${ }^{35}$ Their experiments to increase participation show that citizens face

\footnotetext{
${ }^{35}$ Three different treatments were randomized. The results from the third treatment were already discussed in the section on contract teachers. In the first treatment, the NGO organized meetings in the villages, where school staff and village local government representatives were encouraged to share information about the structure and organization of local service delivery, including the role and activities of the VECs. The second treatment
} 
substantial constraints in getting involved with the improvement of the public education system, even when they care about education and are willing to do something to improve it. ${ }^{36}$ However, when parents are able to overcome the barriers to be involved and are also empowered, having trained school committees may prove to be a good intervention for improving students' performance. ${ }^{37}$ Also, Gertler et al. (2011) study a very inexpensive program in Mexico that involves parents directly managing schools located in disadvantaged rural communities. ${ }^{38}$ They find that empowering parents reduces failure and repetition rates significantly. However, while the program was effective in poor communities, it had no effect in extremely poor communities.

A more direct strategy to provide parents with incentives to enroll their children in school is Conditional Cash Transfer (CCT) programs, which have been implemented in many developing countries. CCT programs provide cash transfers to finance current consumption subject to the "attainment" of certain conditions that foster human capital investments. A detailed review of CCT programs is provided by Behrman et al. in Chapter 5 of this volume

included the activities described in the first treatment, but the NGO members also demonstrated the process of creating "learning report cards" by conducting simple assessments of reading and arithmetic with the local children. The goal behind the design of the second intervention was that community members and parents become sensitized to their children's educational progress.

${ }^{36}$ An average village of about 360 households sent about 100 people to the meetings, yet both the first and second interventions had no impact on community involvement in public schools, and no impact on teacher effort or student learning outcomes in those schools.

\footnotetext{
${ }^{37}$ This is similar to one of the treatments in India's "Extra Teacher Program"; see Duflo et al., forthcoming

${ }^{38}$ The program finances parent associations and motivates parental participation by involving them in the management of primary school grants. They found that the program reduced grade failure by 7.4 percent and grade repetition by 5.5 percent in grades 1 through 3 , although it had no effect on dropout rates.
} 
and also in Galiani (2008). CCT programs have had significant positive impacts on a wide range of outcomes, including educational outcomes. ${ }^{39}$ In the context of CCTs as a complementary intervention, they seem to have a positive effect on equality: the impact on enrollment rates are generally larger for those groups that have lower base-line enrollment rates, lower transition rates from primary to secondary school, girls, or poorer households (Galiani and McEwan, 2011). Also, some potential complementary interventions invovle giving resources to the poor to complement other interventions that do not benefit them directly. Chapter 2 in this volume covers some examples (see also Glewwe et al, 2009). Overall, we think that it is more likely that poor communities adopt complementary interventions that are related to accountability and empowerment or giving incentives to parents rather than those involving an increase in their spending on education.

In summary, we conclude that there is an interesting menu of complementary interventions that could be combined with the school management policies analyzed before in ways that would enhance their positive results and reduce inequality in education outcomes.

\section{Conclusions}

In this survey, we have analyzed three types of School Management interventions: school decentralization, student tracking, and teacher incentives. We cover a non-exhaustive list of empirical papers that exploit non-experimental, quasi-experimental and experimental identification strategies.

In our opinion, for each case, a deeper understanding of their structural mechanisms at work is a key goal for future research in this area. Given the heterogeneous effects of these

\footnotetext{
${ }^{39}$ For a very complete review see Fiszbein et al. (2009).
} 
policies, knowing the channels through which they operate differentially across subpopulations or settings is of high priority. This understanding will aid in designing complementary cost-effective interventions that enhance the effects of the reforms or help to extend its benefits to those that have not been reached.

Overall, we have drawn several conclusions regarding the interventions surveyed, and more importantly, we have raised related topics that require further exploration. Our main findings are that decentralization programs seem to be successful in increasing the average performance of students. However, the better-off communities or schools tend to profit most from this type of intervention, which increases inequality. A goal for future studies would be to understand how school autonomy differentially affects relatively poor and rich communities. Complementary interventions could then be implemented to compensate those that do not gain from decentralization; giving information to promote parental participation through school committees seems to be effective, especially in poorer communities where the decentralized resources are more likely to be diverted to other needs that do not necessarily raise welfare.

Regarding tracking, the experimental evidence suggests that tracking increases the performance of students across all skill levels. However, because there is only one experimental study, and especially because it contrasts with the non-experimental evidence, further experimental evidence is needed. Finally, most of the teacher incentive schemes studied proved to have positive results in terms of reducing absenteeism of teachers and improving the performance of students, although the compensations systems should be designed to discourage teaching to the test. Concerning contract teachers, the empirical evidence also shows favorable impacts on students' test scores and teachers' absenteeism. However, understanding whether this happens because of incentives, decentralization of 
hiring, or through other channels is key to designing better contracts for tenured civil service teachers and profiting most from the combination of the two types of teachers. Also, complementary interventions regarding monitoring of teachers by parental committees or extra hiring of contract teachers to help more disadvantaged students could be useful to increase the average and distributional benefits from this type of intervention.

Finally, school management reforms should be accompanied by programs aimed at stimulating the demand for education of those individuals who are less likely to take advantage of the reforms. This combination of demand and supply interventions seems to be an attractive recipe for promoting and raising education outcomes, which, in turn, will promote long run economic growth in the developing world. 


\section{References}

Alesina, A., R. Baqir and C. Hoxby (2004), "Political Jurisdictions in Heterogeneous Communities," Journal of Political Economy, Vol. 112 (2), pp. 348-396.

Angrist, J. and V. Lavy (1999), “Using Maimonides' rule to estimate the effect of class size on scholastic achievement”. Quarterly Journal of Economics, Vol 114 (2), pp. 533-575.

Argys, L., D. Rees and D. Brewer (1996), “Detracking America’s schools: equity at zero cost?” Journal of Policy Analysis and Management, Vol. 15 (4), pp. 623-645.

Arrow, K. (1951): Social Choice and Individual Values, John Wiley and Sons.

Banerjee, A. and E. Duflo (2011), Poor Economics: A Radical Rethinking of the Way to Fight Global Poverty, Public Affairs, New York.

Banerjee, A., S. Cole, E. Duflo and L. Linden (2007), "Remedying Education: Evidence from Two Randomized Experiments in India," The Quarterly Journal of Economics, Vol. $122(3)$, pp. 1235-1264.

Banerjee A.; Banerji R.; Duflo E.; Glennerster R. and Khemani, S. (2008), ’Pitfalls of participatory programs: evidence from a randomized evaluation in education in India." NBER Working Paper No. 14311.

Barankay, I. and Lockwood, B. (2007), "Decentralization and the Productive Efficiency of Government: Evidence from Swiss Cantons," Journal of Public Economics, Vol. 91, pp. 1197-1218.

Bardhan, P. and D. Mookherjee (2005), "Decentralizing Anti-poverty Program Delivery in Developing Countries," Journal of Public Economics, Vol. 89 (4), pp. 675-704. 
Bardhan, Pranab and Mookherjee, Dilip (2006), "Decentralization and Accountability in Infrastructure Delivery in Developing Countries,” Economic Journal, Vol. 116 (508), pp. 101-127.

Barrera-Osorio, F., T. Fasih, H. Patrinos and L. Santibáñez (2009), “Decentralized DecisionMaking in Schools: The Theory and Evidence on School-Based Management." Washington, DC: World Bank.

Barro, R. and J. Lee (2001), "Schooling quality in a cross-section of countries". Economica, Vol. 68 (272), pp. 465-488.

Benabou, Roland and Tirole, Jean (2006), "Incentives and Prosocial Behavior," American Economic Review, Vol. 96 (5), pp. 1652-1678.

Bennell, P. (2004), "Teacher Motivation and Incentives in Sub-Saharan Africa and Asia," Knowledge and Skills for Development, Brighton.

Benveniste, L., and J. Marshall. 2004. "School Grants and Student Performance: Evidence from the EQIP Project in Cambodia.” Unpublished manuscript, World Bank, Washington, DC.

Berlinski, S., S. Galiani and P. Gertler (2009), "The effect of pre-primary education on primary school performance”. Journal of Public Economics, Volume 93, 2009, pp 219234

Betts, Julian R. and Shkolnik, Jamie L. (2000), "The effects of ability grouping on student achievement and resource allocation in secondary schools," Economics of Education Review, Vol. 19 (1), pp. 1-15.

Bird, R.M. and Vaillancourt, F. (Eds.) (1998), Fiscal Decentralization in Developing Countries. Cambridge, New York and Melbourne: Cambridge University Press. 
Bishop, J. (1995), “The impact of curriculum-based external examinations on school priorities and student learning", International Journal of Education Research, Vol. 23 (8), pp. 653-752.

Bishop, J. (1999), “Are national exit examinations important for educational efficiency?” Swedish Economic Policy Review, Vol. 6(2), pp. 349-398.

Bishop, J. (2006), "Drinking from the fountain of knowledge: Student incentive to study and learn - Externalities, information problems, and peer pressure”. In Hanushek, E.A., Welch, F. Handbook of the Economics of Education: North Holland, pp.909-944.

Bourdon J.; Frölich M. and Michaelowa, K. (2006), "Broadening access to primary education: contract teacher programs and their impact on education outcomes in Africa - an econometric evaluation for the Republic of Niger," in Menckhoff L. (Ed) Pro-poor growth: issues, policies, and evidence. Berlin: Duncker \& Humblot.

Bourdon J.; Frölich, M. and Michaelowa, K. (2007), “Teacher Shortages, Teacher Contracts and Their Impact on Education in Africa," Institute for the Study of Labor (IZA), Berlin.

Bruns, B., D. Filmer and H. Patrinos (2011), Making Schools Work: New Evidence on Accountability Reforms. Washington DC: The World Bank

Burke, M. and T. Sass (2008), "Classroom peer effects and student achievement,” Working Paper 08-5, Federal Reserve Bank of Boston.

Chaudhury, N. and Parajuli, D. (2010), "Giving it Back: Evaluating the Impact of Devolution of School Management to Communities in Nepal.” Mimeo. 
Chaudhury, N., Hammer, J., Kremer, M., Muralidharan, K., \& Rogers, F. H. (2006), "Missing in action: Teacher and health worker absence in developing countries". Journal of Economic Perspectives, 20, 91-116.

Corten, R. and Dronkers, J. (2006), "School achievement of pupils from the lower strata in public, private government-dependent and private government-independent schools: A cross-national test of the Coleman-Hoffer thesis". Educational Research and Evaluation, Vol 12 (2), pp. 179-208.

De Laat, J. and Vegas, E. (2005), "Do Differences in Teacher Contracts Affect Student Performance? Evidence from Togo,” World Development Report 2004 Background Paper, 2005.

Ding, Weili and Lehrer, Steven F. (2007), "Do Peers Affect Student Achievement in China's Secondary Schools?” The Review of Economics and Statistics, Vol. 89 (2), pp. 300-312.

Dinkelman, Taryn and Martínez A., Claudia (2011), "Investing in Schooling in Chile: The Role of Information about Financial Aid for Higher Education," Working Paper No. 1296, Princeton University.

Duflo, Esther; Dupas, Pascaline and Kremer, Michael (2011) "Peer Effects and the Impacts of Tracking: Evidence from a Randomized Evaluation in Kenya", American Economic Review, Vol. 101 (5), pp. 1739-1774.

Duflo, Esther; Dupas, Pascaline and Kremer, Michael (2007), "Peer Effects, Pupil-Teacher Ratios, and Teacher Incentives: Evidence from a Randomized Evaluation in Kenya" Mimeo

Dulfo, E., R. Hanna and S. "Incentives Work: Getting Teachers to Come to School,'Forthcoming, American Economic Review. 
Duthilleul, Y. (2005), "Lessons Learnt in the Use of 'Contract' Teachers," International Institute for Educational Planning, UNESCO.

Faguet, Jean-Paul and Sanchez, Fabio (2008), “Decentralization's Effects on Educational Outcomes in Bolivia and Colombia," World Development, Vol. 36 (7), pp. 1294-1316.

Figlio, David N. and Page, Marianne E. (2002), "School Choice and the Distributional Effects of Ability Tracking: Does Separation Increase Inequality?" Journal of Urban Economics, Vol. 51 (3), pp. 497-514.

Fiszbein, Ariel, and Norbert Schady. 2009. Conditional Cash Transfers: Reducing Present and Future Poverty. World Bank Policy Research Report. The World Bank. Washington, D.C.

Fuchs, T. and L. Woessmann (2007), "What accounts for international differences in student performance? A re-examination using PISA data". Empirical Economics Vol 32 (2-3), pp. 433-462.

Franceschelli, I., S. Galiani and E. Gulmez (2008), "Performance Pay and Productivity of Low- and High-Ability Workers" (December 2008). Available at SSRN: http://ssrn.com/abstract $=1279189$.

Franceschelli, I., S. Galiani and E. Gulmez (2010), "Performance Pay and Productivity of Low- and High-Ability Workers". Labour Economics, Volume 17, 2010, pages 317-322

Galiani, S. (2008), "Reducing Poverty in Latin America and the Caribbean," Report for the Copenhagen Consensus Center and the Inter-American Development Bank.

Galiani, S., P. Gertler and E. Schargrodsky (2008), "School Decentralization: Helping the good get better, but leaving the poor behind," Journal of Public Economics, Vol. 92, pp. 2106-2120. 
Galiani, S. and P. McEwan (2011), "The heterogeneous impact of conditional cash transfers in Honduras", Mimeo

Gertler, Paul J.; Patrinos, Harry A. and Rubio-Codina, Marta (2011), “Empowering parents to improve education: Evidence from rural Mexico," Unpublished manuscript.

Glewwe, Paul; Kremer, Michael and Moulin, Sylvie (2009), "Many children left behind? Textbooks and test scores in Kenya," American Economic Journal: Applied Economics, Vol.1 (1), pp.112-135.

Glewwe, Paul; Ilias, Nauman and Kremer, Michael (2010), “Teacher Incentives,” American Economic Journal: Applied Economics, Vol. 2 (3), pp. 205-27.

Gordon, R.; Kane, T.J., and Staiger, D.O. (2006), “Identifying Effective Teachers Using Performance on the Job," Hamilton Project Discussion Paper No. 2006-01.

Goyal, S. and Pandey, P. (2009), “Contract Teachers.” South Asia Human Development Sector Report No. 28, The World Bank.

Gundlach, E. and L. Woessmann (2001), "The fading productivity of schooling in East Asia", Journal of Asian Economies, Vol. 12 (3), pp. 401-417.

Gunnarsson, Victoria; Orazem, Peter F.; Sánchez, Mario A. and Verdisco, Aimee (2009), "Does Local School Control Raise Student Outcomes? Evidence on the Roles of School Autonomy and Parental Participation," Economic Development and Cultural Change, Vol. 58 (1), pp. $25-52$.

Hanushek, E. (2006), “School resources”. In Hanushek, E.A., Welch, F. Handbook of the Economics of Education: North Holland, pp. 865-908. 
Hanushek, E. and D. Kimko (2000), "Schooling, labor force quality, and the growth of nations". American Economic Review Vol. 90 (5), pp. 1184-1208

Hanushek, E. and Luque, J. (2003), "Efficiency and equity in schools around the world". Economics of Education Review, Vol 22 (5), pp. 481-502.

Hanushek, E.A. and Woessmann, L. (2006), “Does educational tracking affect performance and inequality? Differences-in-differences evidence across countries", Economic Journal, Vol. 116 (510), C63-C76.

Hanushek, E.A. and Woessmann, L. (2011), “The Economics of International Differences in Educational Achievement”, in E.A., Hanushek, Machin, S. and Woessmann, L., Handbook of the Economics of Education: North Holland, pp. 89-199.

Hoffer, T. B. (1992), "Middle school ability grouping and student achievement in science and mathematics", Educational Evaluation and Policy Analysis, Vol. 14, pp. 205-227.

Holmstrom, Bengt and Paul Milgrom (1991), "Multi-Task Principal-Agent Analyses: Linear Contracts, Asset Ownership and Job Design", Journal of Law, Economics and Organization, Vol. 7, pp. 24-52

Jackson, C. Kirabo (2010), "Do Students Benefit From Attending Better Schools?: Evidence From Rule-based Student Assignments in Trinidad and Tobago," Economic Journal, Vol. 120 (549), pp. 1399-1429.

Jensen, Robert (2010), “The (Perceived) Returns to Education and the Demand for Schooling," Quarterly Journal of Economics, Vol. 125 (2), pp. 515-548.

Jimenez, E. and Y. Sawada (1999), "Do Community-Managed Schools Work? An Evaluation of El Salvador's EDUCO Program”, World Bank Economic Review, Vol. 13 (3), pp. 415-441. 
Jimenez, E. and Y. Sawada (2003), "Does Community Management Help Keep Kids in Schools? Evidence Using Panel Data from El Salvador's EDUCO Program," CIRJE FSeries CIRJE-F-236, CIRJE, Faculty of Economics, University of Tokyo.

Kaplow, L. and S. Shavell (2002): Fairness versus Welfare, Harvard University Press.

Kerckhoff, A.C. (1986), "Effects of ability grouping in British secondary schools," American Sociological Review, Vol. 51, pp. 842-858.

King, E. and B. Ozler (2005), "What's Decentralization Got to do with Learning? The Case of Nicaragua's School Autonomy Reform,” 21COE, Interfaces for Advanced Economic Analysis, Kyoto University.

Kremer, M., S. Moulin and R. Namunyu (2003), "Decentralization: A Cautionary Tale," Poverty Action Lab Paper No. 10.

Kremer, Michael; Muralidharan, Karthik; Chaudhury, Nazmul; Hammer, Jeffrey and Rogers, F. Halsey (2005), “Teacher Absence in India,” Journal of the European Economic Association, Vol. 3, pp. 658-667.

Krueger, A.B. (1999), "Experimental Estimates Of Education Production Function”, Quarterly Journal of Economics, Vol. 114 (2), pp. 497-532.

Layard, R, S. Nickell and R. Jackman (1991), Unemployment: macroeconomic performance and the labour market Oxford University Press, 1991

Lassibille, G., J-P. Tan, C. Jesse, and T. Nguyen (2010). "Managing for results in primary education in Madagascar: Evaluating the impact of selected workflow interventions", World Bank Economic Review 24(2):303-329. 
Lazear, E. (2000), "Performance pay and productivity”, American Economic Review, 90, pp. 1346-1361.

Madeira, Ricardo. (2007). "The Effects of Decentralization on Schooling: Evidence From the Sao Paulo State Education Reform.” Mimeo

Manning, Allen and Pischke, Jörn-Steffen (2006), “Comprehensive Versus Selective Schooling in England \& Wales: What Do We Know?" Centre for the Economics of Education Working Paper No. CEEDP006.

Mookherjee, D. (2006): “Poverty Persistence and the Design of Antipoverty Policies”, in Understanding Poverty, A. Banerjee, R. Benabou and D. Mookherjee (eds.), Oxford University Press.

Muralidharan, Karthik and Sundararaman, Venkatesh (2010), "Contract Teachers: Experimental Evidence from India," Mimeo.

Muralidharan, K. and V. Sundararaman (2011), “Teacher Performance Pay: Experimental Evidence from India," Journal of Political Economy, Vol. 119, No. 1, pp. 39-77.

Nguyen, Trang (2008), “Information, Role Models and Perceived Returns to Education: Experimental Evidence from Madagascar," Working Paper, MIT.

Oates, W. (1972), Fiscal Federalism New York: Harcourt Brace Jovanovich

Olken, Benjamin A. (2006), "Corruption and the costs of redistribution: Micro evidence from Indonesia," Journal of Public Economics, Vol. 90, pp. 853-870.

Paes de Barros, R. and Mendoça, R. (1998), “The Impact of Three Institutional Innovations in Brazilian Education,” in W. D. Savedoff(Ed.) Organization Matters: Agency 
Problems in Health and Education in Latin America. Washington DC: Inter-American Development Bank.

Pop-Eleches, C. and M. Urquiola (2011), “Going to a better school: Effects and behavioral responses”, NBER Working Paper No. 16886

Pradhan, Menno, Suryadarma, Daniel, Beatty, Amanda, Wong, Maisy, Alishjabana, Armida, Gaduh, Arya and Prama Artha, Rima, Improving Educational Quality Through Enhancing Community Participation: Results from a Randomized Field Experiment in Indonesia (May 2011). Available at SSRN: $\underline{\text { http://ssrn.com/abstract=1862143 }}$

PISA (2009), "PISA 2009 Results. What Makes a School Succesful? Resources, Policies and Practices. Volume IV."

Rivkin, S. , E. Hanushek and J. Kain. (2005), “Teachers, Schools, and Academic Achievement." Econometrica 73:417-58.

Salinas, P., and A. Sole-Olle (2009), "Evaluating the effects of decentralization on educational outcomes in Spain,” Institut d'Economia de Barcelona (IEB), Working Papers 2009/10.

Schouetz, G., Ursprung, H.W. and Woessmann, L. (2008), "Education policy and equality of opportunity”, Kyklos, Vol 61 (2), pp. 279-308.

Urquiola, M. and E. Verhoogen (2009), "Class size caps, sorting, and the regression discontinuity design" American Economic Review, 99(1), 179-215.

Vandenberghe, V. and Robin, S. (2004), "Evaluating the effectiveness of private education across countries: A comparison of methods". Labour Economics, Vol 11 (4), pp. 487506. 
Woessmann, L. (2003), “Schooling resources, educational institutions, and student performance: The international evidence", Oxford Bulletin of Economics and Statistics, Vol. 65 (2), pp. 117-170.

Woessmann, L. (2005), “The effect heterogeneity of central examinations: evidence from TIMSS, TIMSS-Repeat and PISA", Education Economics, Vol 13 (2), pp. 143-169.

Woessmann, L.; Luedemann, E. Schuetz, G.; and West, M.R. (2009), School Accountability, Autonomy, and Choice around the World, Edward Elgar.

Zimmerman, D. (2003), "Peer effects in academic outcomes: Evidence from a natural experiment", Review of Economics and Statistics 85(1), 9-23. 
Table 1 (School decentralization)

\begin{tabular}{|c|c|c|c|c|c|c|}
\hline Name & Methodology & Place/Date & Population & $\begin{array}{l}\text { Dependant } \\
\text { Variable }\end{array}$ & $\begin{array}{c}\text { Independent Variable / } \\
\text { Reform / Treatment }\end{array}$ & Results \\
\hline $\begin{array}{c}\text { Galiani, Gertler } \\
\text { and } \\
\text { Schargrodsky } \\
\text { (2008) }\end{array}$ & $\begin{array}{l}\text { Panel of } \\
\text { schools; } \\
\text { Differences-in- } \\
\text { differences } \\
\text { (DiD) }\end{array}$ & $\begin{array}{l}\text { Argentina, } \\
1994-1999\end{array}$ & $\begin{array}{l}\text { Fifth-year } \\
\text { secondary } \\
\text { students }\end{array}$ & $\begin{array}{l}\text { Standardized Math } \\
\text { and Spanish test } \\
\text { scores }\end{array}$ & $\begin{array}{l}\text { Central government } \\
\text { transferred all its secondary } \\
\text { schools to provincial control. }\end{array}$ & $\begin{array}{l}\text { Decentralization had an overall positive effect on student test scores: } \\
\text { math test scores increased } 3.5 \% * * \\
\text { and Spanish tests rose } 5.4 \% \%^{* *} \text { on average after } 5 \text { years of decentralized } \\
\text { administration.. However, decentralization had no significant impact on } \\
\text { poor municipalities. }\end{array}$ \\
\hline Madeira (2007) & $\begin{array}{c}\text { Panel of } \\
\text { schools; DiD }\end{array}$ & $\begin{array}{c}\text { Brazil, 1996- } \\
2003\end{array}$ & $\begin{array}{l}\text { All public } \\
\text { primary } \\
\text { school } \\
\text { students in the } \\
\text { state of São } \\
\text { Paulo }\end{array}$ & $\begin{array}{l}\text { Dropout, failure, } \\
\text { enrollment rates } \\
\text { and school } \\
\text { resources }\end{array}$ & $\begin{array}{c}\text { Sao Paulo State Education } \\
\text { Reform }\end{array}$ & $\begin{array}{l}\text { On average, one year of decentralization increases dropouts by } \\
0.6 \text { s.d.**, failure rates by } 1 \mathrm{s.d} . * * \text { and increased VCRs and TVs per } \\
\text { hundred students by } 0.1 \text { s.d.**. One year of decentralization increased } \\
\text { enrollment by } 0.2 \mathrm{~s} . \mathrm{d} \text {. on average. The results are partially driven by } \\
\text { the democratization of the school access. Effects where more perverse } \\
\text { in rural and poor areas, widening the gap between good and bad } \\
\text { schools. }\end{array}$ \\
\hline $\begin{array}{l}\text { Salinas Pena } \\
\text { and Sole Olle } \\
\text { (2009) }\end{array}$ & $\begin{array}{c}\text { Panel of } \\
\text { provinces; DiD }\end{array}$ & $\begin{array}{l}\text { Spain, 1987- } \\
2005\end{array}$ & $\begin{array}{l}16 \text { year old } \\
\text { students, } \\
\text { passing from } \\
\text { compulsory to } \\
\text { non- } \\
\text { compulsory } \\
\text { education }\end{array}$ & $\begin{array}{l}\text { Survival rate as a } \\
\text { measure of } \\
\text { educational } \\
\text { attainment }\end{array}$ & $\begin{array}{l}\text { Spanish decentralization } \\
\text { period. Dummy variable for } \\
\text { decentralized provinces }\end{array}$ & $\begin{array}{l}\text { Decentralization had a positive effect on enrollment in non-vocational } \\
\text { training programs at the expenses of vocational training programs, } \\
\text { which might reflect a better match between population preferences and } \\
\text { educational policies. The effect on survival rate is more than } 1.6 \%{ }^{* *} \\
\text { percent on average, but it appears to be positively correlated with per } \\
\text { capita income of the region }\end{array}$ \\
\hline $\begin{array}{l}\text { Paes de Barros } \\
\text { and Mendoca } \\
\quad(1998)\end{array}$ & $\begin{array}{l}\text { Panel of states; } \\
\text { DiD }\end{array}$ & $\begin{array}{c}\text { Brazil, 1981- } \\
1993\end{array}$ & $\begin{array}{l}\text { Primary } \\
\text { school } \\
\text { students }\end{array}$ & $\begin{array}{l}\text { Repetition and } \\
\text { dropout rates, } \\
\text { standardized test } \\
\text { scores }\end{array}$ & $\begin{array}{l}\text { Dummies for intervention, } \\
\text { using the different timing of } \\
\text { the interventions across } \\
\text { states }\end{array}$ & Decrease on repetition rate $(-2.4 * * *$ points $)$; no impact on test scores \\
\hline $\begin{array}{c}\text { Jimenez and } \\
\text { Sawada (1999) }\end{array}$ & $\begin{array}{l}\text { Cross section of } \\
\text { students; IV for } \\
\text { EDUCO school }\end{array}$ & $\begin{array}{l}\text { El Salvador, } \\
1996\end{array}$ & $\begin{array}{l}\text { Third grade } \\
\text { students }\end{array}$ & $\begin{array}{l}\text { Standardized math } \\
\text { and language test } \\
\text { scores and student } \\
\text { absenteeism }\end{array}$ & EDUCO program. & $\begin{array}{l}\text { Decentralization improved students' language skills }\left(0.43 \text { s.d. }{ }^{\dagger}\right) \text { and } \\
\left.\text { diminished student absences (by around } 3.5^{*}\right)\end{array}$ \\
\hline
\end{tabular}




\begin{tabular}{|c|c|c|c|c|c|c|}
\hline $\begin{array}{l}\text { Jimenez and } \\
\text { Sawada } \\
\text { (2003) }\end{array}$ & $\begin{array}{l}\text { School-level } \\
\text { panel data; } \\
\text { Heckman } \\
\text { correction } \\
\text { model }\end{array}$ & $\begin{array}{l}\text { El Salvador } \\
1996-2003\end{array}$ & $\begin{array}{l}\text { 3rd grade } \\
\text { students in } \\
\text { rural schools }\end{array}$ & $\begin{array}{l}\text { Retention and } \\
\text { repetition rates }\end{array}$ & EDUCO program. & $\begin{array}{l}\text { Students in EDUCO schools are } 0.36^{* *} \text { more likely to continue in } \\
\text { school after } 2 \text { years. }\end{array}$ \\
\hline $\begin{array}{l}\text { King and Özler } \\
\text { (1998) }\end{array}$ & $\begin{array}{l}\text { Matching } \\
\text { schools that } \\
\text { participated and } \\
\text { did not } \\
\text { participate in the } \\
\text { reform; IV for } \\
\text { de facto } \\
\text { autonomy }\end{array}$ & $\begin{array}{l}\text { Nicaragua, } \\
1995-1997\end{array}$ & $\begin{array}{l}\text { Both primary } \\
\text { and secondary } \\
\text { school } \\
\text { students }\end{array}$ & $\begin{array}{l}\text { School enrollment } \\
\text { rates, levels of } \\
\text { student grade } \\
\text { repetition and } \\
\text { dropouts, math and } \\
\text { language test }\end{array}$ & $\begin{array}{l}\text { A governmental program } \\
\text { transferred key management } \\
\text { tasks from central authorities } \\
\text { to school councils. }\end{array}$ & $\begin{array}{l}\text { Autonomy de jure does not affect student's performance. Higher de } \\
\text { facto autonomy in some administrative decisions, spatially in the } \\
\text { ability to hire and fire school personnel, is correlated with a better } \\
\text { student's achievement. A one standard deviation increase in the } \\
\text { number of decisions made by school council at the primary level is } \\
\text { associated with an increase of } 6.73 \%^{* *} \text { in math test score, or } 4.05 \%^{* *} \\
\text { in for Spanish test score in secondary schools. }\end{array}$ \\
\hline $\begin{array}{c}\text { Faguet and } \\
\text { Sanchez (2008) }\end{array}$ & $\begin{array}{l}\text { Panel of states; } \\
\text { Before-after } \\
\text { estimator }\end{array}$ & $\begin{array}{l}\text { Bolivia, 1991- } \\
\text { 1996, and } \\
\text { Colombia, } \\
\text { 1993-2004 }\end{array}$ & $\begin{array}{l}\text { Primary and } \\
\text { secondary } \\
\text { school } \\
\text { students. All } \\
\text { Bolivian } \\
\text { municipalities } \\
\text { and } 85 \% \text { of } \\
\text { Colombian } \\
\text { municipalities } \\
\end{array}$ & $\begin{array}{l}\text { Expenditure and } \\
\text { investment by } \\
\text { sectors. }\end{array}$ & $\begin{array}{l}\text { Dummy for the years after } \\
\text { the reform has taken place }\end{array}$ & $\begin{array}{l}\text { In Colombia: increase in student enrollment in public schools (by } \\
\qquad 0.1^{* *} \text { ) } \\
\text { In Bolivia: change in investment patterns of local governments, making } \\
\text { them more responsive to local needs }\end{array}$ \\
\hline $\begin{array}{l}\text { Benveniste and } \\
\text { Marshall } \\
\text { (2004) }\end{array}$ & $\begin{array}{l}\text { Randomization } \\
\text { by district }\end{array}$ & $\begin{array}{l}\text { Cambodia, } \\
1999-2003\end{array}$ & $\begin{array}{l}\text { Primary } \\
\text { school } \\
\text { students }\end{array}$ & $\begin{array}{l}\text { Dropout and pass } \\
\text { rates, standardized } \\
\text { test scores }\end{array}$ & $\begin{array}{l}\text { Treated schools received a } \\
\text { grant that was invested in } \\
\text { priorities determined by } \\
\text { local stakeholders, as well as } \\
\text { technical advisors to help } \\
\text { planning and implementation } \\
\text { activities }\end{array}$ & $\begin{array}{c}\text { Increase pass rates }(4.2 \% * * * \text { and } 4.3 \% * * * \text { after two and three years of } \\
\text { the program), lowered dropout }(1.1 \% * * * \text { and } 1.2 \% * * * \text { after two and } \\
\text { three years of the program, respectively), improved achievement }\left(0.13^{*}\right. \\
\text { standard deviations })\end{array}$ \\
\hline
\end{tabular}


Table 2 (Tracking)

\begin{tabular}{|c|c|c|c|c|c|c|}
\hline Name & Methodology & Place/Date & Population & $\begin{array}{l}\text { Dependant } \\
\text { Variable }\end{array}$ & $\begin{array}{c}\text { Independent Variable / Reform / } \\
\text { Treatment }\end{array}$ & Results \\
\hline $\begin{array}{l}\text { Duflo, Dupas and } \\
\text { Kremer (2011) }\end{array}$ & Randomized Trial & $\begin{array}{l}\text { Kenya, 2005- } \\
\quad 2007\end{array}$ & Grade 1 students & $\begin{array}{c}\text { Standardized math } \\
\text { and language test } \\
\text { scores }\end{array}$ & $\begin{array}{c}121 \text { primary schools received funds } \\
\text { to hire an extra contract teacher and } \\
\text { split the class into two sections. In } \\
60 \text { randomly selected schools, } \\
\text { students were randomly assign to } \\
\text { each class, while in the other } 61 \\
\text { they were ranked by prior } \\
\text { achievement }\end{array}$ & $\begin{array}{l}\text { Tracking had positive effects on all students. Students in tracking } \\
\text { schools have on average } 0.14^{*} \text { s.d. higher test scores than those in } \\
\text { non-tracking schools }\left(0.16^{* *} \text { one year after the experiment }\right. \\
\text { finished). }\end{array}$ \\
\hline $\begin{array}{c}\text { Betts and Shkolnik } \\
\text { (2000) }\end{array}$ & $\begin{array}{l}\text { Panel of students; } \\
\text { using test scores } \\
\text { before some schools } \\
\text { began to track }\end{array}$ & $\begin{array}{l}\text { USA, 1987- } \\
\quad 1992\end{array}$ & $\begin{array}{l}\text { Students at grades } \\
7 \text { to } 12\end{array}$ & $\begin{array}{c}\text { Standardized math } \\
\text { tests }\end{array}$ & Dummy for tracking schools & $\begin{array}{l}\text { High ability students are benefited from tracking while low ability } \\
\text { students are not benefited not hurt. }\end{array}$ \\
\hline $\begin{array}{c}\text { Hanushek and } \\
\text { Woessmann (2005) }\end{array}$ & $\begin{array}{l}\text { Panel of countries; } \\
\text { difference in } \\
\text { difference }\end{array}$ & $\begin{array}{l}18-26 \\
\text { countries, } \\
1995-2003\end{array}$ & $\begin{array}{l}\text { 4th to } 8 \text { th grade } \\
\text { students }\end{array}$ & $\begin{array}{l}\text { Standardized } \\
\text { international tests } \\
\text { in reading, } \\
\text { mathematics and } \\
\text { science }\end{array}$ & $\begin{array}{c}\text { Dummy if the student attends to a } \\
\text { school in a system that tracks in that } \\
\text { grade }\end{array}$ & $\begin{array}{l}\text { Early tracking increases educational inequality: it can account for } \\
\text { one quarter of the difference in inequality between the most } \\
\text { equitable and the most inequitable country. There is also some } \\
\text { evidence that early tracking reduce mean performance. }\end{array}$ \\
\hline $\begin{array}{l}\text { Burke and Sass } \\
\qquad(2008)\end{array}$ & $\begin{array}{l}\text { Panel of students; } \\
\text { student and teacher } \\
\quad \text { fixed effects }\end{array}$ & $\begin{array}{c}\text { Florida, USA, } \\
1999-2004\end{array}$ & $\begin{array}{l}\text { Students at grades } \\
\quad 3 \text { to } 10\end{array}$ & $\begin{array}{c}\text { Standardized } \\
\text { reading and math } \\
\text { test scores }\end{array}$ & $\begin{array}{l}\text { Average fixed effects of classroom } \\
\text { peers }\end{array}$ & $\begin{array}{l}\text { Teacher and peer quality is correlated, resulting in possible bias } \\
\text { on previous studies that omitted teacher variables. Low achieving } \\
\text { students experience a } 0.82 \text { point boost to their math score from } 1 \\
\text { point increase in the mean peer's score, whereas high ability } \\
\text { students will receive } 0.1 * * \text { point increase under de same } \\
\text { treatment. Strong positive effect for the lower achieving students } \\
\text { from having peers from the higher quartile of the distribution, but } \\
\text { the opposite happens for high achieving students with poor } \\
\text { quality peers. }\end{array}$ \\
\hline
\end{tabular}




\begin{tabular}{|c|c|c|c|c|c|c|}
\hline $\begin{array}{l}\text { Figlio and Page } \\
\text { (2002) }\end{array}$ & $\begin{array}{l}\text { Panel of students in } \\
\text { Tracking and Non- } \\
\text { Tracking schools; } \\
\text { Difference in } \\
\text { Difference, IV for } \\
\text { tracking status }\end{array}$ & $\begin{array}{l}\text { USA, 1987- } \\
\quad 1994\end{array}$ & $\begin{array}{l}\text { 8th to } 10 \text { th grade } \\
\text { students }\end{array}$ & $\begin{array}{c}\text { Change from } 8 \text { th to } \\
\text { 10th grade in } \\
\text { student's IRT math } \\
\text { score }\end{array}$ & $\begin{array}{l}\text { Instrument tracking status of the } \\
\text { school and track of the student } \\
\text { (reported by the principal of the } \\
\text { school) with the number of courses } \\
\text { required for state graduation, the } \\
\text { number of schools in the county, } \\
\text { and the fraction of voters in the } \\
\text { county who voted for President } \\
\text { Reagan }\end{array}$ & No evidence that tracking hurts low-ability children. \\
\hline Hoffer (1992) & $\begin{array}{l}\text { Cross section of } \\
\text { schools; propensity } \\
\text { score matching }\end{array}$ & $\begin{array}{l}\text { USA, 1987- } \\
\quad 1989\end{array}$ & $\begin{array}{l}\text { 7th graders and } \\
10 \text { th graders }\end{array}$ & $\begin{array}{c}\text { Math and science } \\
\text { standardized test } \\
\text { scores }\end{array}$ & $\begin{array}{l}\text { Dummy variables indicating if a } \\
\text { student is placed in an } \\
\text { heterogeneous group, or in a high, } \\
\text { middle, or low ability group }\end{array}$ & $\begin{array}{c}\text { There is evidence of a positive effect of tracking for high ability } \\
\text { students }\left(0.08^{* *} \text { and } 0.24 \text { standard deviations in science and }\right. \\
\text { mathematics, respectively) and a negative effect for low ability } \\
\text { students (around } 0.3^{* *} \text { and } 0.34^{* *} \text { standard deviations), summing } \\
\text { up to a negative average effect. }\end{array}$ \\
\hline $\begin{array}{l}\text { Argys, Rees and } \\
\text { Brewer (1996) }\end{array}$ & $\begin{array}{c}\text { Cross section of } \\
\text { students, OLS with a } \\
\text { selectivity correction } \\
\text { term }\end{array}$ & USA, 1988 & $\begin{array}{l}\text { 10th grade students } \\
\text { in public schools }\end{array}$ & $\mid \begin{array}{c}\text { Standardized math } \\
\text { test scores }\end{array}$ & $\begin{array}{l}\text { Dummy variables indicating if a } \\
\text { student is placed in an } \\
\text { heterogeneous group, or in a high, } \\
\text { middle, or low ability group }\end{array}$ & $\begin{array}{l}\text { Differential effect of tracking, helping students in high ability } \\
\text { tracks and students in average ability tracks }(5 \% * * \text { and } 2 \% * * \\
\text { gain in math test score, respectively) on the expenses of students } \\
\text { in low ability tracks (5\%** lose). They find a small positive net } \\
\text { effect, suggesting an overall efficiency gain }\end{array}$ \\
\hline
\end{tabular}


Table 3 (Teacher Incentives)

\begin{tabular}{|c|c|c|c|c|c|c|}
\hline Name & Methodology & Place/Date & Population & Dependant Variable & Independent Variable / Reform / Treatment & Results \\
\hline $\begin{array}{c}\text { Muralidharan and } \\
\text { Sundararaman } \\
(2011)\end{array}$ & Randomized trial & $\begin{array}{c}\text { India } \\
2005-2007\end{array}$ & $\begin{array}{l}\text { Primary } \\
\text { school } \\
\text { teacher }\end{array}$ & $\begin{array}{l}\text { Standardized math and } \\
\text { language test scores }\end{array}$ & $\begin{array}{l}\text { The program provided bonus payments to teachers } \\
\text { based either on the average improvement in test scores } \\
\text { of all school students (group incentives) or on the } \\
\text { average improvement of their own students. }\end{array}$ & \begin{tabular}{|c|} 
Students in treated schools perform $0.27 * * *$ \\
$0.17^{* * *}$ standard deviations better in math and \\
language test, respectively. The average bonus was \\
$3 \%$ of annual pay. Incentive schools also perform \\
significantly better than other schools that received \\
additional schooling inputs of a similar value
\end{tabular} \\
\hline $\begin{array}{c}\text { Glewwe, Kremer } \\
\text { and Ilias (2010) }\end{array}$ & Randomized trial & $\begin{array}{c}\text { Kenya } \\
1998-1999\end{array}$ & $\begin{array}{l}\text { Primary } \\
\text { school } \\
\text { teacher }\end{array}$ & \begin{tabular}{|} 
Teacher attendance, \\
homework assignment, \\
pedagogy, test preparation \\
sessions and student test \\
scores on district exams
\end{tabular} & $\begin{array}{l}\text { The program offered schools the opportunity to provide } \\
\text { gifts to teachers if students performed well. It provided } \\
\text { prizes to teachers in grades } 4 \text { to } 8 \text { based on the } \\
\text { performance of the school as a whole on the district } \\
\text { exams in each year. Prizes ranged from } 21 \text { to } 43 \% \text { of } \\
\text { typical teacher monthly salaries. }\end{array}$ & $\begin{array}{c}\text { Students in schools with a teacher incentive program } \\
\text { were significantly more likely to take exams and had } \\
\text { higher test scores in the short run. Teachers in } \\
\text { program schools had no higher attendance rates or } \\
\text { homework } \\
\text { assignment rates. Pedagogy and student dropout } \\
\text { rates were similar across schools. Teachers in } \\
\text { program schools increased test preparation activities } \\
\text { and encouraged students enrolled in school to take } \\
\text { the test. }\end{array}$ \\
\hline $\begin{array}{c}\text { Duflo Hanna and } \\
\text { Ryan } \\
(2010)\end{array}$ & $\begin{array}{c}\text { Randomized trial } \\
\text { and structural } \\
\text { model }\end{array}$ & $\begin{array}{c}\text { India, 2003- } \\
2004\end{array}$ & $\begin{array}{c}\text { Rural school } \\
\text { students }\end{array}$ & $\begin{array}{l}\text { Teacher absenteeism, and } \\
\text { students test scores }\end{array}$ & $\begin{array}{l}\text { In } 60 \text { randomly chose schools out of } 120 \text {, the teacher } \\
\text { received a camera with a tramper-proof date and time } \\
\text { function. Teachers were instructed to make on of the } \\
\text { students take a photograph of the teacher and other } \\
\text { students at the start and end of each school day. Each } \\
\text { teacher was then paid according to the days worked }\end{array}$ & $\begin{array}{l}\text { Teachers' absenteeism fell by } 21 * * * \text { percentage } \\
\text { points, and student's test scores increased by } \\
0.17^{* * *} \text { standard deviations }\end{array}$ \\
\hline
\end{tabular}




\begin{tabular}{|c|c|c|c|c|c|c|}
\hline \multicolumn{7}{|c|}{ Contract Teachers } \\
\hline $\begin{array}{l}\text { Duflo, Dupas and } \\
\text { Kremer (2009) }\end{array}$ & Randomized trial & $\begin{array}{l}\text { Kenya, 2005- } \\
2007\end{array}$ & $\begin{array}{l}\text { First grade } \\
\text { students }\end{array}$ & $\begin{array}{c}\text { Student test scores, } \\
\text { teacher absenteeism } \\
\text { and time spent actively } \\
\text { teaching, student } \\
\text { attendance }\end{array}$ & $\begin{array}{l}70 \text { schools out of } 140 \text { were } \\
\text { randomly selected to receive a } \\
\text { treatment, consisting on hiring an } \\
\text { extra contract teacher to split the } \\
\text { class in two, and randomly divide } \\
\text { the students to each class }\end{array}$ & $\begin{array}{l}\text { Students randomly assigned to contract teachers score } 0.23 * * \text { s.d. } \\
\text { higher and an } 11 \% \text { increase in grade promotion than their } \\
\text { schoolmates assigned to civil service teachers. Contract teachers } \\
30 \text { p.p. more likely to be found in class teaching than civil servant } \\
\text { teachers. This effect persist in the long run in schools where local } \\
\text { communities where trained on how to monitor contract teachers. } \\
\text { These schools tend to keep contract teachers after the program has } \\
\text { ended. }\end{array}$ \\
\hline $\begin{array}{l}\text { Barnerjee, Banerji, } \\
\text { Duflo, Glennerster } \\
\text { and Khemani (2008) }\end{array}$ & Randomized trial & $\begin{array}{l}\text { India, 2005- } \\
\quad 2006\end{array}$ & $\begin{array}{l}\text { Primary school } \\
\text { children }\end{array}$ & Reading and math test & $\begin{array}{l}\text { NGOs trained volunteers to teach } \\
\text { children to read and organized } \\
\text { remedial reading camps (outside } \\
\text { the school) }\end{array}$ & $\begin{array}{l}\text { Treatment had positive impact on learning: the average child who } \\
\text { could not read anything and attended the camp was } 60 \% * * \text { points } \\
\text { more likely to decipher letters after a year than a comparable child } \\
\text { in a control village }\end{array}$ \\
\hline $\begin{array}{l}\text { Banerjee, Cole, } \\
\text { Dulfo and Linden } \\
\quad(2007)\end{array}$ & Randomized trial & $\begin{array}{l}\text { India, 2001- } \\
\quad 2003\end{array}$ & $\begin{array}{l}\text { Disadvantage } \\
\text { students at } \\
\text { grades } 3 \text { and } 4\end{array}$ & $\begin{array}{l}\text { Student test scores, } \\
\text { teacher absenteeism }\end{array}$ & $\begin{array}{c}\text { The program hired young women } \\
\text { to teach students lagging behind } \\
\text { in treated schools. }\end{array}$ & $\begin{array}{l}\text { The effect was positive for all children and higher for those at the } \\
\text { bottom third of the distribution than at for those at the top third } \\
\left(0.47^{* * *} \text { standard deviations versus } 0.23^{* * *} \text { standard deviations }\right)\end{array}$ \\
\hline $\begin{array}{l}\text { Muralidharan and } \\
\text { Sundararaman } \\
(2010)\end{array}$ & Randomized trial & $\begin{array}{l}\text { India, 2005- } \\
\quad 2007\end{array}$ & $\begin{array}{l}\text { Students at } \\
\text { grades } 1 \text { to } 5\end{array}$ & $\mid \begin{array}{c}\text { Standardized math and } \\
\text { language test scores, } \\
\text { absenteeism rates }\end{array}$ & $\begin{array}{l}100 \text { randomly-chosen } \\
\text { government-run rural schools } \\
\text { were provided with contract } \\
\text { teachers }\end{array}$ & $\begin{array}{c}\text { Students in schools with an extra contract teacher perform better } \\
\text { by } 0.15^{* * *} \text { in math's and } 0.9^{* * *} \text { in language standard deviations. } \\
\text { Contract teachers were also } 9 \% \%^{* * *} \text { less likely to be absent than } \\
\text { civil servant teachers }\end{array}$ \\
\hline $\begin{array}{l}\text { Burde and Linden } \\
\text { (2010) }\end{array}$ & Randomized Trial & $\begin{array}{l}\text { Afghanistan, } \\
\text { 2007-2008 }\end{array}$ & $\begin{array}{l}\text { Primary school } \\
\text { students }\end{array}$ & $\begin{array}{c}\text { Enrollment rate. } \\
\text { Standardized math and } \\
\text { language test scores }\end{array}$ & $\begin{array}{c}\text { In randomly selected villages, the } \\
\text { program provides educational } \\
\text { material and training for locally- } \\
\text { recruited educated individuals to } \\
\text { serve as teachers in village-based } \\
\text { schools }\end{array}$ & $\begin{array}{l}\text { Village-based schools improved children performance. School } \\
\text { enrollment increased by } 42 \% * * * \text { and test scores by } 1.2^{* * *} \text { s.d.. } \\
\text { The effect on enrollment where stronger for girls than for boys, } \\
\text { thus alleviating the gender gap in enrollment. }\end{array}$ \\
\hline $\begin{array}{l}\text { Bourdon, Frolich y } \\
\text { Michaelowa } \\
\text { (2006) }\end{array}$ & $\begin{array}{l}\text { Cross section of } \\
\text { students; } \\
\text { Propensity score } \\
\text { matching }\end{array}$ & $\begin{array}{l}\text { Niger, 2000- } \\
2001\end{array}$ & $\begin{array}{l}\text { Students in the } \\
\text { 2nd and 5th } \\
\text { grade }\end{array}$ & $\begin{array}{c}\text { Standardized math and } \\
\text { French test scores }\end{array}$ & Dummy for contract teachers & $\begin{array}{l}\text { Contract teachers have enable Niger to enhance enrolment, } \\
\text { although there is some evidence of deteriorated education for } \\
\text { contract teacher students in the } 2 \text { nd grade }\left(-5,43^{*} \text { points in math }\right. \\
\text { French test scores), the difference is small and not significant at a } \\
\qquad 10 \% \text { level for } 5 \text { th grade students }\end{array}$ \\
\hline
\end{tabular}




\begin{tabular}{|c|c|c|c|c|c|c|}
\hline $\begin{array}{l}\text { Bourdon, Frolich y } \\
\text { Michaelowa } \\
\text { (2007) }\end{array}$ & $\begin{array}{l}\text { Cross section of } \\
\text { students; Non- } \\
\text { parametric } \\
\text { matching } \\
\text { estimator }\end{array}$ & $\begin{array}{c}\text { Mali, } \\
\text { 2001/2002; } \\
\text { Niger and Togo, } \\
\text { 2000/2001 }\end{array}$ & $\begin{array}{l}\text { 2nd and 5th } \\
\text { grade students }\end{array}$ & $\begin{array}{l}\text { Standardized math and } \\
\text { French test scores }\end{array}$ & Dummy for contract teachers & $\begin{array}{l}\text { Contract teachers programs appear to have better impact for low } \\
\text { achieving students than high achieving students: in Mali, students } \\
\text { in the bottom of the ability distribution assign to contract teachers } \\
\text { perform } 14^{* *} \text { to } 33^{* * *} \text { p.p. higher than those assigned to civil } \\
\text { servant teachers, while there is no significant difference for high } \\
\text { ability students. In Niger high ability students with contract } \\
\text { teachers score between } 19 \text { and } 25(* * \text { to } * * *) \text { p.p. lower while } \\
\text { coefficients are not significant for low ability students. Overall, } \\
\text { they had a positive impact when applied in a more decentralized } \\
\text { way (in Mali) and a negative impact in centralized cases (in Niger), } \\
\text { probably because of better monitoring from local communities. }\end{array}$ \\
\hline $\begin{array}{c}\text { Alcazar, Chaudhury, } \\
\text { Hammer, Kremer, } \\
\text { Muralidharan and } \\
\text { Rogers } \\
\text { (2006) }\end{array}$ & $\begin{array}{l}\text { Cross section of } \\
\text { teachers; } \\
\text { Matching } \\
\text { estimates }\end{array}$ & Peru, 2002 & $\begin{array}{c}\text { Primary school } \\
\text { teachers }\end{array}$ & $\begin{array}{c}\text { Absence rates, } \\
\text { measure with } \\
\text { unannounced visits }\end{array}$ & Dummy for contract teachers & Contract teachers $12-13 \% * * *$ more likely to be absent \\
\hline $\begin{array}{c}\text { Goyal and Pandey } \\
\text { (2009) }\end{array}$ & $\begin{array}{l}\text { Cross section of } \\
\text { students; } \\
\text { Propensity score } \\
\text { matching }\end{array}$ & $\begin{array}{c}\text { Madhya } \\
\text { Pradesh, India, } \\
2006\end{array}$ & $\begin{array}{l}\text { Teachers in } \\
\text { grades } 1 \text { to } 5\end{array}$ & $\begin{array}{c}\text { Test scores, teacher } \\
\text { attendance and activity }\end{array}$ & Dummy for contract teachers & $\begin{array}{l}\text { Contract teachers absent } 27 \% \text { of the time and found teaching } 37 \% \\
\text { of the time, while regular teachers absent } 37 \% \text { of the time and } \\
\text { found teaching } 25 \% \text { of the time. These results worsen for contract } \\
\text { teachers in second contract year but where still better than regular } \\
\text { teachers. Difference in absenteeism and activity significant at } 5 \% \\
\text { and 1\% level, respectively }\end{array}$ \\
\hline & & & & & \multicolumn{2}{|c|}{$*, * *$ and $* * *$ are significance at $10 \%, 5 \%$ and $1 \%$ level, respectively; ${ }^{\dagger}=$ not significant at $10 \%$ level } \\
\hline
\end{tabular}


Figure 1
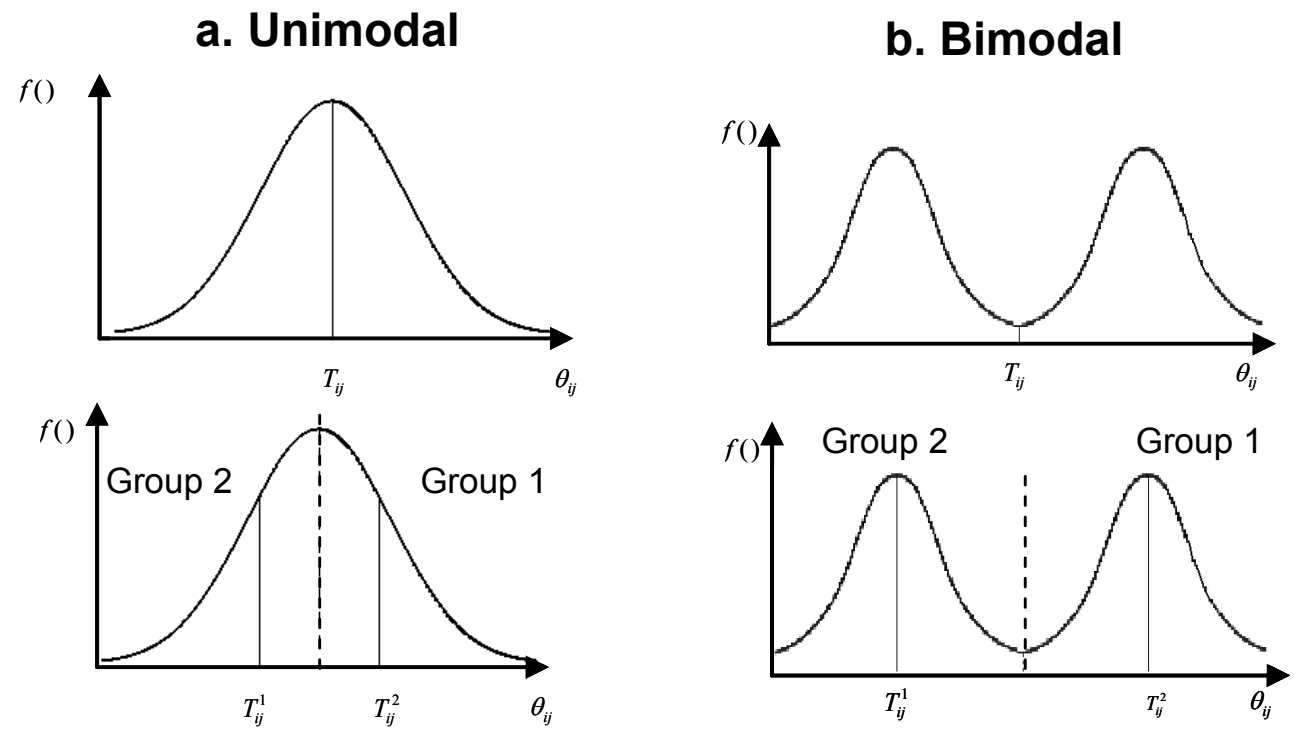


\section{Appendix A - solution to the decentralized problem.}

In the decentralized case, given the government education effort $b_{i j}$, the problem for community $i j$ is:

$$
\operatorname{Max}_{\left\{a_{i j}\right\}}\left(\left(\kappa_{i j} a_{i j}\right)^{\alpha}+\left(\hat{\gamma}_{i j} b_{i j}\right)^{\alpha}\right)^{\frac{1}{\alpha}}-a_{i j}
$$

The first order condition for an interior solution is:

$$
a_{i j}^{d}\left(b_{i j}\right)=b_{i j} \frac{\hat{\gamma}_{i j}}{\kappa_{i j}}\left(\kappa_{i j}^{\frac{\alpha}{\alpha-1}-1}\right)^{-\frac{1}{\alpha}}
$$

Since there are no economies of scale, we can study the problem of the government in each particular community $i j$ separately:

$$
\operatorname{Max}_{\left\{b_{i j}\right.} x \theta_{i j}\left[\left(\left(\kappa_{i j} a_{i j}^{d}\left(b_{i j}\right)\right)^{\alpha}+\left(\hat{\gamma}_{i j} b_{i j}\right)^{\alpha}\right)^{\frac{1}{\alpha}}-a_{i j}^{d}\left(b_{i j}\right)\right]-b_{i j}^{2}
$$

This objective function may differ in cases where the educational spending is financed in a way that may distort incentives. ${ }^{40}$ After substituting for $a_{i j}^{d}$, the objective function becomes:

$$
\operatorname{Max}_{\left\{b_{i j}\right\}} \theta_{i j} b_{i j} \hat{\gamma}_{i j}\left(1-\kappa_{i j}^{\frac{\alpha}{1-\alpha}}\right)^{\frac{\alpha-1}{\alpha}}-b_{i j}^{2} .
$$

The first order condition for an interior solution yields:

$$
b_{i j}^{d}=\frac{\theta_{i j} \hat{\gamma}_{i j}}{2}\left(1-\kappa_{i j}^{\frac{\alpha}{1-\alpha}}\right)^{\frac{\alpha-1}{\alpha}} \text {. }
$$

\footnotetext{
${ }^{40}$ For example, Kenya has a mixed educational system in which local communities are allowed to build their schools and should pay non-teachers expenditures, whereas the central government is in charge of assigning teachers to schools and paying their salaries (as well as setting the curriculum and administering national tests). This obviously introduces distortions: Kremer et al (2003) show that this system generates local communities with too many small schools, rather than fewer, larger schools, and where reallocating expenditures from teachers to nonteacher inputs and reducing the cost of education could improve welfare.
} 
Finally, evaluating $a_{i j}^{d}\left(b_{i j}\right)$ at $b_{i j}^{d}$ we obtain:

$$
a_{i j}^{d}=\frac{\theta_{i j} \hat{\gamma}_{i j}}{2}\left(1-\kappa_{i j}^{\frac{\alpha}{1-\alpha}}\right)^{\frac{\alpha-2}{\alpha}} \kappa_{i j}^{\frac{\alpha}{1-\alpha}}
$$

And evaluating $e_{i j}\left(a_{i j}, b_{i j}\right)$ at $b_{i j}^{d}$ and $a_{i j}^{d}\left(b_{i j}^{d}\right)$ we get the educational outcome:

$$
e_{i j}^{d}=\frac{\theta_{i j} \hat{\gamma}_{i j}^{2}}{2}\left(1-\kappa_{i j}^{\frac{\alpha}{1-\alpha}}\right)^{\frac{\alpha-2}{\alpha}}=\frac{\theta_{i j} \hat{\gamma}_{i j}^{2}}{2} \lambda\left(\kappa_{i j}, \alpha\right)
$$

